\title{
O pensamento de Vygotsky nas reuniões da ANPEd (1998-2003)
}

\author{
Maria Teresa de Assunção Freitas \\ Universidade Federal de Juiz de Fora
}

\section{Resumo}

Este artigo analisa os trabalhos fundamentados no pensamento de Vygotsky encontrados da $21^{\text {a }}$ até a 26 Reunião Anual da ANPEd, no período de 1998 a 2003, com o objetivo de compreender como esse referencial teórico está sendo apropriado pelos autores participantes desse evento da área da Educação.

0 texto está organizado em três partes. Em primeiro lugar descreve-se o processo da pesquisa. Em seguida, são apresentados e discutidos os dados quantitativos do material analisado, presentes nas tabelas que figuram em anexo. A terceira parte se constitui em uma análise qualitativa, na qual se explicitam que referências bibliográficas são as mais utilizadas nos trabalhos examinados, que temas e conceitos da abordagem vygotskiana predominam nessa produção e a apropriação da teoria revelada nos textos. Nessa parte são destacados alguns trabalhos em especial, que parecem oferecer uma contribuição mais valiosa para a construção do conhecimento nesse campo, avançando teoricamente e expandindo os conceitos originais do autor em questão. Conclui-se o artigo tecendo algumas reflexões sobre a atual apropriação do pensamento de Vygotsky, revelada nos trabalhos analisados, dialogando com a tese de doutorado da autora, realizada doze anos atrás, que, abordando a mesma temática, focalizou a chegada dos autores da abordagem histórico-cultural no Brasil, o começo da difusão de suas idéias e os esforços iniciais de incorporação de seus conceitos. Finalmente, levantam-se algumas implicações que o estudo feito pode trazer para os educadores brasileiros e estudiosos de Vygotsky.

\section{Palavras-chave}

Vygotsky - Educação - Apropriação atual. 


\title{
Vygotsky's thought in the ANPEd Meetings (1998 - 2003)
}

\author{
Maria Teresa de Assunção Freitas \\ Universidade Federal de Juiz de Fora
}

\begin{abstract}
This article analyzes the works based on Vygotsky's thought presented at the annual ANPEd (National Association for Graduate Studies and Research in Education) meetings from 1998 to 2003, aiming at an understanding of how that theoretical framework is being incorporated by the authors that participate in those events. The text is organized into three parts. Firstly it describes the research process followed here. It then introduces and discusses the quantitative data extracted from the material analyzed, which is presented in the attached tables. The last part is a qualitative analysis that shows which bibliographical references are the most frequently used sources, which themes and concepts from the Vygotskyan approach predominate in the works investigated, and the incorporation of the theory revealed by the texts. In this last part some of the works are highlighted, which seem to offer a more valuable contribution to the construction of the knowledge in this field, advancing the theory and expanding on Vygotsky's original concepts. The article is concluded with some thoughts on the current incorporation of Vygotsky's thought, as revealed in the works analyzed here, contrasting it with the author's doctoral thesis written twelve years ago, where she dealt with the same issue and focused on the arrival in Brazil of authors of the historical-cultural approach, the beginning of the diffusion of their ideas and the initial efforts to incorporate their concepts. Finally, some implications are raised of the present work to Brazilian educators and to readers of Vygotsky.
\end{abstract}

\section{Keywords}

Vygotsky - Education - Current incorporation.

\section{Contact:}

Maria Teresa de Assunção Freitas

Av. Independência, 2100 apto. 802

36025-290 - Juiz de Fora - MG

e-mail: mtl@acessa.com.br 
"Uma obra explode as fronteiras de seu tempo, ela vive através dos séculos, dito de outra forma, na grande temporalidade, e, fazendo isso não é raro que essa vida (e é sempre verdadeira para uma grande obra) resulte mais intensa e mais plena que no tempo de sua contemporaneidade."

Mikhail Bakhtin

\section{Introdução}

Ao receber o convite para participar de um estudo analítico sobre as produções nacionais a respeito do tema "Vygotsky e educação" senti uma satisfação muito grande. Percebi que essa seria uma oportunidade de retomar de alguma forma a pesquisa desenvolvida em minha tese de doutorado (Freitas, 1992), dando a ela uma certa continuidade. Nessa tese, que posteriormente deu origem ao livro $O$ pensamento de Vygotsky e Bakhtin no Brasil (Freitas, 1994), ${ }^{1}$ procurei compreender como esses autores tornaram-se presentes entre nós, capturando o momento de sua chegada ao nosso país no final da década de 1970, o inicio da difusão de suas idéias nos anos 1980, e o esforço de apropriação de seus conceitos no começo dos 1990. Para tanto, entrevistei 24 educadores brasileiros, que produziam conhecimento nessa área, mapeando e construindo a história da chegada e difusão dos postulados sócio-históricos no Brasil. Com o passar do tempo, decorridos doze anos do trabalho realizado, considerei interessante um novo estudo que pudesse mostrar como a teoria vygotskiana está sendo apropriada no nosso meio educacional. 0 que aconteceu nesse espaço de tempo? Até que ponto as perguntas então levantadas estão sendo respondidas e as prospecções feitas estão se concretizando?

Movida por esse interesse aceitei o desafio e lancei-me numa nova pesquisa. Mas de que maneira seria possível capturar o conhecimento que está sendo produzido no Brasil a partir do pensamento de Vygotsky? Vários foram os caminhos que se me apresentaram: a análise de livros publicados nos últimos anos sobre o autor, ou a partir dele; um estudo de artigos publicados em periódicos da área de Educação; uma pesquisa envolvendo as teses e dissertações que utilizaram Vygotsky como referencial teórico. Refletindo sobre as possibilidades e dificuldades envolvidas nessas três alternativas, acabei decidindo-me por uma quarta opção que me pareceu mais viável e interessante: mapear o que se tem produzido a partir do referencial vygotskiano em um dos eventos mais importantes e significativos da área da Educação: a Reunião Anual da ANPEd. Esse evento se realiza anualmente e reúne educadores de todo o país e até mesmo pessoas de outras nacionalidades. Cada reunião se organiza mediante atividades especificas de seus Grupos de Trabalho (GTs) e atividades mais gerais envolvendo todos os participantes. A apresentação da produção acadêmica no evento tem as seguintes modalidades: trabalhos e pôsteres apresentados nos GTs, trabalhos encomendados a especialistas em determinadas temáticas, seções especiais e minicursos. A opção pelas reuniões da ANPEd prendeu-se a dois motivos: a facilidade de acesso aos textos completos disponiveis em CD-ROM e no site da associação e também devido ao fato de os trabalhos nelas divulgados representarem um reflexo da produção dos programas de pósgraduação presente nos seus grupos de pesquisa e nas teses e dissertações defendidas.

Assim, neste artigo, analiso a produção de trabalhos com base no pensamento de Vygotsky encontrada desde a $21^{\text {a }}$ até a $26^{\text {a }}$ Reunião Anual da ANPEd, portanto, cobrindo o período de 1998 a 2003. Este recorte de tempo permitiu-me o acesso aos textos em sua integra, que começaram a ser disponibilizados, de uma forma sistemática, a partir de 1998. Também, foi meu interesse, focalizar o momento atual, atentando para o que se tem produzido sobre o tema nos últimos seis anos.

1. No livro em questão focalizo o pensamento de dois autores: Vygotsky e Bakhtin. Neste artigo vou dialogar com os dados que dizem respeito apenas a Vygotsky. 
Organizo o artigo fazendo em primeiro lugar a descrição do processo de pesquisa. Em seguida, apresento e discuto os dados quantitativos do material analisado. Para uma análise qualitativa dos textos faço uma síntese das principais temáticas neles abordadas e dos conceitos vygotskianos que as sustentam, tecendo também considerações sobre a apropriação do pensamento de Vygotsky revelada nos trabalhos analisados. Finalmente, levanto algumas implicações que o estudo feito pode trazer para os educadores brasileiros e estudiosos de Vygotsky.

\section{O processo de pesquisa}

A pesquisa relacionada à produção baseada em Vygotsky nos GTs da ANPEd foi iniciada delimitando o foco de estudo em dez Grupos de Trabalho: GT 04 - Didática; GT 07 - Educação de Crianças de 0 a 6 anos; GT 08 - Formação de Professores; GT 10 - Alfabetização, Leitura e Escrita; GT 13 - Educação Fundamental; GT 15 - Educação Especial; GT 16 - Educação e Comunicação; GT 18 - Educação de Pessoas Jovens e Adultas; GT 19 Educação Matemática e GT 20 - Psicologia da Educação. A opção por estes GTs foi tomada após uma primeira leitura dos livros de resumos referentes às Reuniões da ANPEd a serem focalizadas. Por meio dessa leitura foi possivel perceber que estes GTs eram os que apresentavam indícios de produção sobre Vygotsky.

A partir dessa opção, foi iniciada a leitura mais aprofundada dos resumos de trabalhos e pôsteres apresentados, referentes aos GTs em questão das reuniões da ANPEd a serem estudadas. Após essa leitura, foi feita uma triagem dos resumos que demonstravam ter como fundamentação a teoria de Vygotsky. Todo esse material foi posteriormente lido por mim em conjunto com o grupo de bolsistas responsável pelo levantamento preliminar, ${ }^{2}$ discutindo-se e decidindo-se quanto a presença da teoria de Vygotsky nos trabalhos em questão. Após este levantamento e selecionados os trabalhos, fo- ram impressos os textos completos, encontrados em disquetes (21 Reunião), no CD-ROM histórico, ${ }^{3}$ nos CD-ROMs das $23^{\mathrm{a}}, 24^{\mathrm{a}}, 25^{\mathrm{a}}, 26^{\mathrm{a}}$ reuniões, e também no site da ANPEd. ${ }^{4}$

Considerando interessante ampliar o corpus da pesquisa, busquei identificar também para análise os textos dos trabalhos encomendados, minicursos e seções especiais percorrendo o mesmo processo utilizado para os trabalhos e pôsteres apresentados. Porém, devido a insuficiência de informações sobre os minicursos, e a dificuldade de acesso à totalidade dos textos das seções especiais que, na maioria das vezes, não são disponibilizados pelos autores, decidi por não utilizá-los como fonte de dados. ${ }^{5}$

Para melhor visualização quantitativa dos dados obtidos, foram organizadas tabelas relacionadas às três modalidades de trabalho e à sintese geral dos totais de pôsteres, trabalhos encomendados e trabalhos apresentados, em cada reunião e em cada GT, com a indicação daqueles nos quais o referencial vygotskiano se faz presente (Tabelas 1 e 2 , respectivamente).

Terminado esse levantamento inicial, foram assinalados e computados nas Referências Bibliográficas de cada texto impresso os livros de autoria de Vygotsky.

2. Este trabalho foi desenvolvido no interior da pesquisa "Letramento Digital e aprendizagem na era da Internet: um desafio para a formação de professores", em andamento no grupo de pesquisa Linguagem, Interação e Conhecimento (LIC), da Faculdade de Educação da UFJF, coordenado pela professora Maria Teresa de A. Freitas e que conta com o apoio do CNPq e Fapemig. Para a coleta e tabulação de dados foi importante o trabalho das bolsistas de IC: Damares Aparecida Campos, Mirella do Vale Perotta (PIBIC/CNPq) e Roberta Bertges Amaral (BIC/UFJF). A confecção das tabelas e gráficos contou com o suporte de Walter Alexandre Bicalho participante voluntário do LIC.

3. Trata-se de um CD-ROM publicado em 2002 , comemorando os 25 anos de ANPEd, no qual foi possível encontrar muitos dos trabalhos referentes a reuniões anteriores que não constavam dos outros CD-ROMs que só começaram a existir a partir da 23a Reunião.

4. Alguns textos foram também encontrados em diferentes números da Revista Brasileira de Educação, em outras publicações produzidas pelos GTs e em livros publicados a partir dos trabalhos divulgados nas Reuniões da ANPEd que estão todos referenciados nas Referências Bibliográficas. 5. A ANPEd tem procurado resolver esse problema nos dois últimos anos e está conseguindo reunir, não em sua totalidade mas em um número bem expressivo, os textos referentes às seções especiais tanto no seu site quanto nos CD-ROMs das respectivas reuniões. Quanto aos minicursos além dos resumos dos mesmos não são encontradas outras informações a respeito. 
Foi elaborada uma ficha de leitura para os textos, na qual se pedia: um comentário geral dos mesmos, a indicação dos conceitos vygotskianos presentes, uma análise da apropriação do autor referente a esses conceitos, a informação de autores vygotskianos usados ${ }^{6}$ com base nas referências bibliográficas.

\section{Uma análise quantitativa dos dados}

A partir dos dados organizados em tabelas foi possivel encontrar interessantes indicadores da produção acadêmica sobre Vygotsky nas Reuniões da ANPEd. Nas seis Reuniões analisadas $\left(21^{\text {a }}\right.$ a $\left.26^{\text {a }}\right)$, foram ao todo apresentados 1047 textos, incluindo 292 pôsteres, 81 trabalhos encomendados e 674 trabalhos apresentados. ${ }^{7}$ Destes, 87 trabalhos (8,31\%) trazem Vygotsky como referência, o que à primeira vista parece pouco, mas que na realidade é um número significativo, levando-se em conta que, há doze anos, em minha pesquisa anterior já citada (Freitas, 1994), a iniciante produção de artigos ou livros referentes a Vygotsky concentrava-se em poucos autores, todos eles professores de programas de pós-graduação nas áreas de Educação, Psicologia e Linguagem, introdutores de seu pensamento no Brasil. Agora, novos autores despontam entre estudantes da pós-graduação das referidas áreas ou mestres $\mathrm{e}$ doutores dela egressos. Listadas as procedências dos autores dos textos, foram identificadas 35 instituições de ensino superior brasileiras. Entre essas, algumas concentram um maior número de textos como UFJF, USP, Unicamp, Unimep, UFG, Unesp. Um outro dado, que torna significativo esse resultado, é perceber que, num evento específico da área da Educação, dos vinte GTs da ANPEd, dez GTs (50\%) contam com a presença de Vygotsky entre seus trabalhos e isso se apresenta num movimento contínuo, que vai da $21^{\text {a }}$ até a $26^{\text {a }}$ Reunião, como bem demonstram as tabelas no final deste artigo. É importante considerar que a presença desse referencial teórico se manteve durante os seis anos, em todas as Reuniões, nas três modalidades de trabalhos dos GTs focalizados. Um maior percentual de produção vygotskiana $(13,77 \%)$ foi encontrado na $23^{\text {a }}$ Reunião; e na

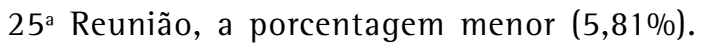
Mas em 2003, na 26a Reunião, o interesse foi

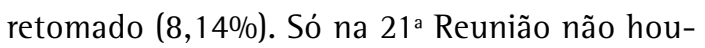
ve apresentação de trabalhos encomendados focalizando o pensamento de Vygotsky, mas a soma dos trabalhos encomendados das cinco reuniões seguintes, marcou visivelmente esse tipo de produção. Foram ao todo dez trabalhos encomendados equivalendo a 12,35\% de um total de 81 . É interessante observar que na $22^{\text {a }}$ Reunião foi expressiva a presença de trabalhos encomendados: 45,45\%, pois, dos onze trabalhos encomendados, cinco versavam sobre Vygotsky. Os textos trazendo a perspectiva de Vygotsky sempre estiveram incluidos, embora em pequenas porcentagens, nas seções de pôsteres de todas as seis reuniões, o que pode ser comprovado pelo total geral de 4,79\%. Nos trabalhos apresentados nos GTs, os textos vygotskianos aparecem com mais força do que nos pôsteres, oscilando entre três $(3,19 \%)$ na $25^{\text {a }}$ Reunião e chegando a $21(19,44 \%)$ na $23^{\text {a }}$ Reunião. No total do período, os trabalhos apresentados atingiram o número de 63 (9,35\%). Observo ainda que a maior incidência de presença de Vygotsky nas seções de pôsteres foi na 25a Reunião: Quatro (9,09\%); entre os trabalhos encomendados foi na $22^{\text {a }}$ Reunião: Cinco (45,45\%); e entre os trabalhos apresentados foi na 23a Reunião: 21 (19,44\%).

\footnotetext{
6. Neste trabalho estiveram presentes as seguintes participantes do LIC: Maria Teresa de A Freitas (coordenadora), Ana Paula Sampaio Pereira, Alessandra Sexto Bernardes, Bruna Sola Ramos, Patrícia Vale Cunha (mestres em Educação pelo PPGE/UFJF), Olívia Paiva Fernandes (mestranda do PPGE/UFJF) e Carolina Paiva Andrade (Bolsista de IC-PROBIC/Fapemig). Também colaboraram nesta análise as mestrandas do PPGE não vinculadas ao LIC: Ana Catarina Noronha e Paula de Deus V. F. Moura.

7. Foram computados todos os trabalhos e pôsteres aceitos pelos GTs, incluindo, portanto, os apresentados e os excedentes, pois, estes últimos, embora não apresentados oralmente, foram publicados. Quanto aos trabaIhados encomendados alguns organizados em forma de mesa-redonda ou com a presença de um debatedor também apresentando um texto, foram todos computados como apenas um trabalho encomendado, de acordo com o que constava na programação das Reuniões da ANPEd.
} 
Analisando a produção total de cada GT, no conjunto das seis reuniões, pude concluir que três GTs concentram de modo expressivo os textos sobre Vygotsky: GT-20 Psicologia da Educação: vinte (18,02\%); GT-10 Alfabetização, Leitura e Escrita: dezessete (15,74\%); GT-15 Educação Especial: treze (13,54\%). Essa maior incidência de textos vygotskianos nesses GTs pode ser compreendida a partir das seguintes reflexões. Vygotsky é um autor da psicologia que, criticando as tendências psicológicas de seu tempo, se propôs a construir uma nova teoria psicológica que atendesse o homem como um todo: corpo e mente na sua interação com a cultura e o social. Sua teoria psicológica é também considerada como uma teoria educacional, pois, de acordo com Bruner (1987), educação para Vygotsky é muito mais do que o desenvolvimento das potencialidades individuais, implicando a expressão histórica e o crescimento da cultura humana da qual o homem procede. Daí se depreende um maior interesse sobre esse autor num GT cujo foco é a Psicologia da Educação. Vygotsky coloca no centro de sua teoria psicológica a linguagem, considerando-a nas suas duas dimensões: a comunicativa e a organizadora do pensamento, constituidora da consciência. Dedicou muitos de seus escritos e pesquisas às questões da relação entre linguagem e pensamento e ao desenvolvimento da escrita. Assim, no GT 10, que trata especificamente das questões da alfabetização-leitura e escrita, as referências a Vygotsky são naturalmente esperadas. Uma outra grande preocupação do autor russo foi com a Educação Especial, deixando em sua obra um livro específico sobre o assunto: Fundamentos de defectología (Vygotsky, 1997), no qual apresenta uma posição de vanguarda, avançada para sua época, em relação ao deficiente, por ele considerado não como deficiente mas diferente, mostrando que essa diferença não é tanto física, biológica, mas principalmente social, no plano da insuficiente interação com o outro, com a cultura. Restaurada essa interação, a deficiência apresenta-se de forma positiva, centrada nas suas possibilidades e não em suas dificuldades. Daí que se justifica plenamente a sua presença significativa no GT 15 , de Educação Especial.

Numa ordem decrescente em relação à produção vygotskiana, situam-se em seguida: GT 07 - Educação de crianças de 0 a 6 anos: nove (8,82\%); GT 19 - Educação Matemática: seis (8,00\%); GT 18 - Educação de Pessoas Jovens e Adultas: sete $(7,53 \%)$. A obra de Vygotsky focaliza a criança de um modo especial, preocupando-se com o desenvolvimento das funções mentais superiores, da linguagem, abordando a temática dos jogos e brincadeiras e da imaginação, o que pode explicar a sua presença num GT dedicado à educação infantil. Ele traz uma nova concepção de desenvolvimento como algo complexo e contínuo, com grande ênfase no papel do meio, da cultura, o que conseqüentemente traz implicações para a educação de jovens e adultos. No GT 19, de Educação Matemática, os textos vygotskianos talvez representem a busca por uma matemática mais relacionada com o cultural e que possibilite uma efetiva aprendizagem. 0 interesse pela obra de Vygotsky no GT 08 - Formação de Professores: quatro $(2,80 \%)$ - está em uma fase inicial. Talvez isso possa se desenvolver à medida que seus participantes começarem a compreender a importância que Vygotsky confere ao professor e como ele pode contribuir para uma formação docente mais contextualizada, crítica e reflexiva. Por outro lado, parece que o autor já vai ganhando confiança no GT 13 Educação Fundamental: cinco (4,76\%) e também no GT 4 Didática: quatro (4,08\%). 0 GT no qual sua penetração é ainda muito pequena é o GT 16 Educação e Comunicação, com apenas dois $(1,72 \%)$.

\section{Os livros que fundamentam os textos}

Até o final da década de 1980, as editoras brasileiras tinham publicado a tradução de apenas três livros de Vygotsky: a Martins Fon- 
tes foi responsável pela publicação de Formação social da mente, cuja primeira edição data de 1984, e de Pensamento e linguagem, lançado em 1987. Linguagem, desenvolvimento e aprendizagem foi publicado em 1988 pela Editora ícone. Em 1991 surgiu a tradução, publicada pela Editora Moraes, do livro Psicologia e pedagogia numa autoria conjunta de Vygotsky, Luria e Leontiev. Só a partir de 1996 é que outras traduções de livros de Vygotsky aparecem no mercado brasileiro (Vygotsky e Luria,1996; Vygotsky, 1996; 1998; 1999; 1999; 2000; 2001; 2003).

Analisando as referências bibliográficas dos 87 textos baseados em Vygotsky, apresentados nas Reuniões da ANPEd, encontrei indicações de que os livros do autor mais citados são Formação social da mente com 41 citações $(47,13 \%)$ e Pensamento e linguagem com 33 citações $(37,93 \%),{ }^{8}$ sendo que sua tradução completa feita por Paulo Bezerra, direto do russo e publicada em 2001 pela Martins Fontes com o título de $A$ construção do pensamento e da linguagem, foi citada duas vezes (2, $30 \%$ ), o que eleva esse resultado para 35 citações, portanto, 40,22\%.9 0 livro Fundamentos de defectologia, tomo $\mathrm{V}$ das Obras escogidas (Vygotsky,1997), que foi citado quase que especificamente pelos autores do GT de Educação especial, ocupando o terceiro lugar em ordem de citação: treze vezes (14,08\%), está bem distante dos dois primeiros. Em seguida aparecem com nove citações (dez, 34\%) os livros Linguagem, desenvolvimento, aprendizagem e Historia del desarrollo de las funciones psíquicas superiores presente na edição espanhola de suas obras completas Obras Escogidas, tomo 111 (1995). Citados cinco vezes (5,75\%) estão Teoria e métodos em psicologia e uma tradução em espanhol La imaginación y el arte em la infância publicado no México em 1987. Com quatro citações (4,68\%), aparece o livro: Estudos sobre a história do comportamento, que é um trabalho conjunto de Vygotsky e Luria (1996). Em seguida com duas citações (2, 38\%), há o livro Desenvolvimento psicológico na Infância (1998). Outros livros do autor são citados apenas uma vez. (Vigotski, 2001; 1982; Vigotski; Luria, 1991).

Esses dados me permitem considerar que apesar do expressivo aumento de publicações de outras obras de Vygotsky em português e do acesso a outras traduções em espanhol entre 1998 a 2003, nos textos apresentados nas Reuniões da ANPEd, durante esse mesmo período, seus autores continuam se referindo basicamente apenas a dois livros: Formação social da mente e Pensamento e linguagem. ${ }^{10}$ Ao centralizarem seu conhecimento apenas nesses textos, não conseguem uma maior apreensão do pensamento do autor em seu conjunto. Além disso, é preciso lembrar que a tradução brasileira de Pensamento e linguagem, em suas edições de junho de 1987 até a atual de 2003, foi realizada a partir de uma tradução americana da qual foram retirados todos os trechos que pudessem dar a Vygotsky uma conotação marxista. Dessa maneira, a tradução americana que deu origem à tradução brasileira constitui-se numa obra reduzida em mais de cem páginas em relação à obra original. Essa redução fragmenta o pensamento do autor, destituindo-o de importantes aspectos relacionados à sua fundamentação teórica básica, dificultando sua real apreensão. De alguma forma, o problema da centralização dos textos apresentados na ANPEd, nessas duas obras de Vygotsky: Formação social da mente e Pensamento e linguagem é compensado com a leitura de outros autores vygotskianos que têm se dedicado ao estudo da obra de Vygotsky. Assim, foi possivel perceber que embora a maioria dos textos sobre o autor russo tenha como referência apenas dois de seus livros, há contudo uma grande presença de livros de diferentes autores

8. Tuleski (2000) também em seu trabalho resultante de uma extensa revisão de literatura, chega a esta mesma conclusão: a grande maioria dos estudos publicados sobre Vygotsky tem por base estas suas duas obras. 9. Entre essas 33 citações estão incluídas três que se referem a traduções da obra em inglês, francês, espanhol e cinco ao tomo II da coleção Obras Escogidas de Vygotsky (1982).

10. Também na pesquisa, por mim realizada em 1992 , foi encontrada essa referência centrada nesses dois livros de Vygotsky. 
brasileiros. Nesse sentido, foi interessante verificar como os autores vygotskianos mais citados se situam entre aqueles por mim entrevistados há doze anos, introdutores de Vygotsky no Brasil, e que se constituem hoje como os interlocutores que fundamentam o pensamento dos novos autores brasileiros. Destes, os mais citados são Jobim e Souza (1994, 1996); Garcia; Castro; Jobim e Souza (1997), Kramer (1993), Kramer; Leite (1998), Freitas (1994, 1994b,) Oliveira (1993, 1995), Smolka (1988, 1991, 1995), Smolka; Góes; Pino (1993, 1997, 1998), Pino (1998, 2000), Góes (1991, 2000b, 2001b), Davis; Silva; Espósito (1989), Oliveira (1994, 1995). Também outros autores brasileiros estão marcando presença nos textos apresentados nas reuniões da ANPEd como Duarte (1996, 2000), Fontana (2000), Moysés (1997), Rojo (2001), Padilha (2000).

São essas leituras brasileiras que embasam os textos divulgados na ANPEd, acrescidos também de alguns autores estrangeiros como Tulviste (1991); Rey (2003); Kozoulin (2002); Moll (1996); Riviére (1985); Wertsch (1985, 1998); Daniels (1994); Van der Veer; Valsiner (1996); Baquero (1998), entre outros. Autores que se referem mais à teoria da atividade também são citados, como Davidov (1982, 1988), Davidov; Zinchenko (1994), Chaiklin (2003). Ao lado destes também são encontradas referências a Luria (1986, 1990) e Leontiev (1978), que complementam o conhecimento da obra de Vygotsky.

\section{Os temas e os conceitos presentes nos textos}

Analisando os textos dos três GTs que apresentaram uma produção mais significativa sobre Vygotsky - GT 20 Psicologia da Educação, GT 10 Alfabetização, Leitura e Escrita e GT 15 Educação Especial -, procurei identificar neles as principais temáticas trabalhadas. No GT de Psicologia os textos se organizam em dois grupos: trabalhos em forma de ensaios e relatos de pesquisa. Os ensaios procuram discutir as contribuições da Psicologia Sócio-histórica para a Psicologia da Educação, as relações entre psicologia e educação, a influência das análises de Lévy-Bruhl no desenvolvimento teórico da psicologia de Vygotsky, a construção da subjetividade infantil através da análise de uma obra literária, a importância da contextualização histórica da obra de Vygotsky e um debate sobre a apropriação de suas idéias no Brasil. Os relatos de pesquisa incidem sobre as questões da criatividade humana, relações entre arte e Psicologia da Educação objetivando uma maior compreensão do comportamento do homem contemporâneo, a formação da identidade de jovens sem-terra como uma construção social, o processo de escolarização e a apropriação da escrita nas aldeias indigenas dos Xacriabá. Também abordam a aprendizagem ${ }^{11}$ em suas relações com o desenvolvimento, com a afetividade, com as interações professor/aluno ou com as tarefas escolares. As pesquisas referem-se ainda às estratégias cognitivas de professores e alunos, às transformações conceituais de professores em formação, aos problemas da indisciplina na escola e, finalmente, analisam a prática de psicólogos escolares e seus fundamentos teóricos.

As temáticas abordadas nos textos vygotskianos no GT de Alfabetização, Leitura e Escrita dizem respeito a pesquisas que se voltam para as questões da leitura e escrita em dois focos: no seu processo de construção e em relação às práticas socioculturais. No primeiro foco são enfatizados aspectos da mediação pedagógica, das interações sociais, do processo ensino/aprendizagem. 0 segundo foco envolve a leitura/escrita de crianças e adolescen-

11. Em algumas traduções brasileiras aprendizagem tem sido traduzida como aprendizado numa tentativa de escapar da falta de precisão do termo na obra de Vygotsky, na qual não fica claro se 0 autor se refere à aprendizagem ou ao ensino. Isso se explica porque em russo a palavra obutchênie significa tanto ensinar como ser ensinado, aprender. Em seus textos Vygotsky emprega a mesma palavra obutchênie para ensino e aprendizagem. Concordando com Bezerra (2001), um dos melhores tradutores de Vygotsky no Brasil, neste texto usamos a palavra aprendizagem significando assimilar conhecimentos, envolvendo processos cognitivos implicados na aquisição de conteúdos e sistematização de conhecimentos. 
tes em diferentes situações escolares e também em ambientes extra-escolares. A questão da escrita é vista na sua relação com a oralidade, cognição e cultura e analisada tanto em seus processos iniciais como em relação à produção de textos e às novas formas de escrita possibilitadas pela internet. Está, portanto, presente uma preocupação com a formação do leitor/ escritor na contemporaneidade, sendo levantadas, nesse sentido, questões que se articulam à pratica docente e formação de professores.

O GT 15 Educação Especial, por sua temática bem específica, concentra-se nas questões da deficiência, preocupando-se de um modo especial com as questões da inclusão do aluno deficiente na escola e na sociedade. Esse aspecto é focalizado em relação aos processos de escolarização e da atuação dos professores como agentes na educação inclusiva. Há uma preocupação com o desenvolvimento cognitivo e a aprendizagem de alunos com deficiências auditivas e mentais. A surdez é a temática mais focalizada nos textos vygotskianos deste GT. Nela se concentra a maior parte dos trabalhos envolvendo questões do desenvolvimento da linguagem, da constituição da escrita e da relação da língua de sinais com a elaboração da escrita. Quanto aos deficientes mentais, são estudados aspectos relativos ao seu processo de simbolização e possibilidades de desenvolvimento cognitivo.

Algumas das temáticas presentes nesses GTs, nos quais a produção sobre Vygotsky é mais significativa, de certa forma se repetem nos demais, assumindo algumas especificidades de acordo com os objetivos de cada um deles. Assim, no GT 7 Educação de Crianças de 0 a 6 anos, os trabalhos se concentram nas questões dos jogos, brincadeiras e imaginação, na construção do conhecimento, e nos processos de formação de conceitos. Há também nesse GT uma discussão sobre as possibilidades que a teoria vygotskiana pode abrir para uma nova forma da compreensão da infância na contemporaneidade. O GT 18 Educação de Pessoas Jovens e Adultas focaliza, de modo especial, as especificidades etárias e socioculturais de jovens e adultos em processo de escolarização, preocupando-se com as questões do conhecimento, da aprendizagem e formação de conceitos envolvendo principalmente a alfabetização, produções de textos e registros matemáticos com suas implicações didáticas. A aprendizagem da matemática é o tema central dos trabalhos vygotskianos do GT 19, Educação Matemática, sendo discutida e relacionada ao desenvolvimento de conceitos matemáticos, mediação do computador e processos de produção coletiva sobre saberes de professores de matemática. Acrescenta aos temas o sentido atribuído ao zero e a implementação curricular como uma ação cultural da escola.

Os GTs 4, Didática, e 08, Formação de Professores, concentram os trabalhos vygotskianos na perspectiva da formação de professores, prática docente e aprendizagem, enquanto o GT 13, Educação Fundamental, centraliza-se nos problemas do fracasso escolar, repetência, cotidiano da escola pública de periferia e as interações entre professor e alunos em contextos de aprendizagem. O GT 16, Educação e Comunicação, é o que apresenta uma menor parcela de trabalhos na perspectiva de Vygotsky, mas são inovadoras as discussões que acontecem em seu interior, pois envolve algumas considerações teórico-metodológicas sobre pesquisar a infância ao usar como instrumento mediador a televisão, e salientar que seu uso pode ser entendido como mediador dos processos de aprendizagem e desenvolvimento.

Vygotsky é chamado a fundamentar todos esses temas a partir dos principais conceitos presentes em sua teoria. Tentando identificar esses conceitos, pude perceber que aparece em primeiro lugar (em 28 trabalhos, 32,18\%) a questão da mediação, compreendida tanto no que se refere à mediação do outro, quanto à mediação semiótica. Este conceito se interliga a outros que são identificados nos textos, como a compreensão do sujeito formado histórica e socialmente na interação com o outro via linguagem, o que possibilita o movimento entre os 
dois planos: do interpessoal para o intrapessoal. Tudo isso compreendido a partir de uma noção de desenvolvimento que articula as duas linhas: a natural-biológica e a sociocultural. É, portanto, na interação com o outro, sob a influência da cultura, que os modos de funcionamento cognitivo surgem, e mediante as quais são construídas as funções mentais superiores.

0 conceito que aparece em segundo lugar é o da aprendizagem, resultante de um processo interativo ou coletivo, como promotora de desenvolvimento, estando presente em 22 (25\%) dos textos analisados. As discussões sobre aprendizagem são complementadas com o conceito de Zona de Desenvolvimento Proximal, a questão da formação dos conceitos no processo de desenvolvimento humano, a articulação entre conceitos espontâneos e científicos, importância do papel da escola e do professor, despontando já um pequeno interesse pela teoria da atividade, envolvendo o papel ativo do aluno na formação do pensamento teórico via conteúdos escolares.

Também estão presentes os conceitos relacionados ao desenvolvimento da linguagem que acontece num processo interativo e leva, via internalização, à constituição do sujeito, da consciência, destacando-se o papel da palavra na formação do pensamento. São enfocados os instrumentos materiais e psicológicos, os signos, chegando-se à linguagem escrita como um sistema simbólico e seu processo de constituição com suas implicações educacionais.

A questão da deficiência está centrada não no defeito orgânico mas nas conseqüências sociais desse defeito. Portanto, é tratada em sua positividade, numa visão prospectiva das suas possibilidades, pensando-se o desenvolvimento do deficiente principalmente no que se refere ao deficiente mental e auditivo. Aí aparece com bastante força o desenvolvimento da linguagem na criança surda via língua de sinais e as características da constituição de sua escrita com idéias voltadas para o ensino do deficiente numa perspectiva inclusiva.
A imaginação na infância se apresenta articulada aos jogos e brincadeiras de faz de conta, que são vistos como possibilidades de simbolização numa atividade preparatória para a construção da escrita e como zona de desenvolvimento proximal que contribui para o desenvolvimento infantil.

Ainda são encontradas referências aos conceitos de Vygotsky em relação à arte como possibilidade de compreensão e o desenvolvimento do processo criativo e da reação estética. 0 contexto histórico social como formador do sujeito merece destaque em alguns trabalhos que se preocupam com a importância de se compreender a teoria de Vygotsky a partir de seus fundamentos ligados ao materialismo histórico dialético e ao momento histórico em que construiu sua obra. Referências são feitas, também, ao seu método dialético de estudo dos fenômenos humanos compreendendo-os em sua historicidade.

\section{A apropriação vygotskiana revelada nos textos}

A análise dos textos apresentados nos dez GTs, durante as seis reuniões da ANPEd focalizadas, permitiu-me identificar a presença de diferentes níveis de apropriação da teoria vygotskiana neles existentes. Procurando compreendê-los, passo a refletir sobre esses diferentes níveis de apropriação, explicitando a leitura que deles faço.

Em um primeiro conjunto de textos, Vygotsky aparece quase por acaso, não se constituindo como o eixo principal da temática abordada. Ele surge incidentalmente, em meio a alguma idéia exposta pelo autor, citado de passagem, não merecendo uma discussão ou análise. Algumas vezes, nem isso acontece, pois ele apenas é referenciado na bibliografia mas, de forma alguma, se percebe no texto a presença de seu pensamento. Outras vezes, ele nem é citado, mas aparecem no texto algumas idéias tributárias suas, sem serem identificadas como tal por quem escreve. Isso pode acontecer 
quando o autor do texto está se baseando em vygotskianos, desconhecendo essa sua filiação teórica. Foi possível encontrar em nove textos $(10,34 \%)$ do material analisado algumas dessas características.

Percebi também alguns textos (onze trabalhos, equivalendo a 12,64\%) nos quais um conhecimento superficial em relação a Vygotsky se reflete na dificuldade de diferenciá-lo de outros autores. 0 desconhecimento dos fundamentos filosóficos que embasam sua teoria dificulta a distinção das diferenças entre autores, podendo levar a uma confusão entre princípios teóricos de perspectivas opostas. Assim, Vygotsky é apresentado junto com Piaget indistintamente, sem um diálogo construtivo entre as suas idéias ou numa conjugação com outros autores, cujos fundamentos são antagônicos ao autor em questão. Vejo aqui, em relação a esses dois conjuntos de textos aos quais estou fazendo referência, cumprir-se um dos receios expostos por mim doze anos atrás (Freitas, 1994): o modismo. Na área da educação o fenômeno da moda é muito comum: é preciso dizer que se conhece, citar determinados autores para mostrar o quanto se está atualizado, em dia com a novidade teórica do momento. Assim, os trabalhos analisados permitem perceber que, de alguma forma, isso está hoje acontecendo com Vygotsky. Entretanto, é possível compreender que essa influência do modismo não é muito preocupante, uma vez que a soma dos percentuais referentes a esses textos (22,98\%), representa o menor índice encontrado.

Há também um grupo de 29 textos analisados $(33,33 \%)$, dos quais faço a seguinte leitura. Os autores citam Vygotsky corretamente, apresentam no início do texto sua intenção em trabalhar com suas idéias e assumilo como um referencial teórico. No entanto, ao chegarem ao tema do artigo ou na análise dos dados apresentados, Vygotsky não mais aparece. Seus conceitos citados mantêm-se desarticulados em relação aos dados analisados e ao todo do artigo. Talvez isso se dê por carência de uma maior fundamentação e de uma leitu- ra mais extensiva e aprofundada. Ficam muito presos a apenas dois livros do autor: Pensamento e linguagem e Formação social da mente, sem um maior conhecimento de sua obra como um todo. Os conceitos do autor são vistos, pois, de uma forma fragmentada e isolados de seus fundamentos filosóficos marxistas. Fica claro que na "arquitetura" do pensamento de um autor, certos conceitos fundamentais não podem ser especificados com base na leitura de apenas alguns de seus textos, mas que é necessário uma compreensão da obra em sua totalidade. Isto é, compreender sua raiz epistemológica, suas fases de elaboração, as condições de sua produção, o contexto sócio-históricocultural em que foi gestada. É perceptível como se repetem os conceitos do autor sem que sejam estabelecidas as necessárias relações entre eles e muitas vezes são apresentados desfocados das idéias defendidas no texto. Há uma justaposição da teoria com o tema: de um lado são expostas as idéias de Vygotsky e, de outro, o autor do texto desenvolve o assunto em questão sem estabelecer um diálogo, sem realizar a esperada articulação. Também situo nesse grupo de textos aqueles que usam conceitos de Vygotsky mas apenas como uma contribuição parcial para o trabalho, o qual está enfocado em outros autores ou perspectivas teóricas afins. Nessa situação, parece que Vygotsky surge por acaso em meio a outros autores. 0 trabalho em si traz citações, conceitos de Vygotsky, mas não se constitui em um texto vygotskiano como tal, articulando forma, conteúdo e método. Seus conceitos são usados descolados de seus fundamentos, de sua historicidade. Enfim, considero que talvez neste nivel de apropriação se encontram os autores que não conseguem demonstrar uma compreensão própria dos conceitos ou da teoria, carecendo de um maior aprofundamento quanto às suas raízes epistemológicas.

Foi gratificante encontrar entre os 87 trabalhos analisados, 38 textos $(43,67 \%)$ que revelam uma apropriação consistente do pensamento de Vygotsky, demonstrando uma fun- 
damentada compreensão de sua teoria ou até indo um pouco mais além, caminhando numa criativa expansão do uso de seus conceitos. Nesses trabalhos, percebo o cumprimento de uma das expectativas por mim já anunciadas: um maior nível de profundidade dos conceitos apreendidos de Vygotsky e uma expansão conceitual. (Freitas, 1994). Estes textos mostram uma visão contextualizada do autor, com um conhecimento de seus fundamentos históricos sociais. São textos que refletem como seus autores se apropriam das idéias de Vygotsky a partir da leitura de um maior número de obras do autor e de seus diferentes interpretes, construindo a sua própria leitura de Vygotsky. Assim, conseguem de forma construtiva e criativa dialogar com as idéias de Vygotsky na construção das temáticas que abordam. Outros vão um pouco mais além chegando até a certos avanços teóricos. Neste sentido, estão incluídos os trabalhos encomendados, e alguns apresentados, nos quais, especialistas da área respaldando-se em vastas bibliografias e com um esforço de reflexão, construído por muita pesquisa e estudo, conseguem uma certa expansão dos conceitos vygotskianos. É uma atualização do pensamento do autor ao nosso momento histórico, às questões que a contemporaneidade e a prática educativa colocam.

Nessa perspectiva destaco alguns trabalhos. Parto inicialmente daqueles que estão preocupados com a contextualização da obra de Vygotsky e seus fundamentos marxistas. Esta é a tônica do texto de Pino (1999), que em um trabalho encomendado no GT de Psicologia, apresenta as implicações da psicologia concreta de Vygotsky para a educação. Nele, Pino afirma que se fosse possível sintetizar em algumas poucas idéias a contribuição de Vygotsky para a compreensão do ser humano, ele apontaria duas: o desenvolvimento psicológico como um processo histórico e a natureza cultural do psiquismo. Ao longo do texto tem a grande preocupação de aprofundar essas duas idéias, buscando Marx como referência para o entendimento do pensamento de Vygotsky. Em um outro texto, Tuleski (2000), com sua voz eloqüente e de tonalidade marxista, mergulha nos conceitos de Marx nos quais Vygotsky se baseou, e instiga e inquieta o leitor sobre uma pertinente e difícil questão: como ler Vygotsky hoje? É possível hoje, num outro momento histórico, numa sociedade marcada pelo modo de produção capitalista e pelo fenômeno da globalização, apreender os conceitos de um autor, gestados na Rússia do início dos anos 1920, num momento revolucionário de construção de uma sociedade comunista? Que significado tinha para a sociedade russa e que significado tem para a sociedade contemporânea? Tuleski levanta em seu trabalho, a hipótese de que a teoria "trasladada para um outro campo, sem considerar o campo que a fez germinar, sofre um processo de assepsia neutralizadora que autoriza sua vulgarização sem ameaça ou suspeita" (2000, p. 1). ${ }^{12}$

Pino (1999), já acenava para uma possibilidade de resposta a essas questões:

o desafio, enquanto essas condições não forem transformadas, é levar em conta a história do meio e conseguir implantar na criança a consciência da sua realidade e da impossibilidade real de superação das limitações que ele the impõe. Como? Este é o desafio. (p. 60)

Os textos de Tuleski e Pino têm para mim uma importância fundamental: são um alerta, chamam a atenção para um ponto essencial na obra de Vygotsky: a presença da historicidade ou concepção histórica de sua teoria. Sem essa concepção é impossivel apreender a riqueza de seus conceitos. Esses autores incitam-nos a uma revisão da leitura de Vygotsky. Estamos conscientes dessa historicidade? Compreendemos o que ele quer realmente dizer com social? 0 que representa o cultural em sua teoria? Qual é a nossa leitura e apropriação desse autor?

12. Talvez essa hipótese esteja pois em consonância com os três primeiros níveis de apropriação da teoria por mim identificados nessa pesquisa. 
Como estas estão presentes nos textos que construímos?

Se num esforço de reflexão e revisão essas questões forem respondidas é possível caminhar numa perspectiva de avanço em relação à teoria. E mais, ao compreender que Vygotsky foi de fato um homem de seu tempo, por estar respondendo aos reclamos de uma nova sociedade que estava se constituindo, pode-se hoje dizer que ao dar condições de olhar para a nossa sociedade atual com um olhar crítico, numa busca de uma transformação emancipatória, ele se torna também, um autor para além de seu tempo.

Nessa mesma linha de pensamento cito o debate "As apropriações das teorias psicológicas pela prática educativa contemporânea: a incorporação de Piaget e de Vygotsky ao ideário pedagógico" promovido na $23^{2}$ Reunião pelo GT 20, Psicologia da Educação. Duarte (2000) polemiza com a tendência que considera dominante entre os educadores que buscam, no terreno da psicologia, uma fundamentação em Vygotsky: a tendência em interpretar as idéias desse psicólogo numa ótica que as aproxima de ideários pedagógicos centrados no tema aprender a aprender. Assim chega a uma hipótese:

a aproximação entre as idéias vygotskianas e as idéias neoliberais e pós-modernas não pode ser efetuada sem um grande esforço por descaracterizar a psicologia desse autor soviético, desvinculando-a do universo filosófico marxista e do universo político socialista. (Duarte, 2000, p. 2)

Considera que isso se realiza de duas diferentes maneiras: 1) a aproximação entre a teoria vygotskiana e a concepção psicológica epistemológica-interacionista-construtivista de Piaget; 2) a interpretação da teoria vygotskiana como uma espécie de relativismo culturalista centrado nas interações lingüísticas intersubjetivas de uma forma que a aproxima do ideário pósmoderno.
Debatendo com Duarte compreendo e participo de sua preocupação com a apropriação do pensamento de Vygotsky entre educadores brasileiros, preservando as bases que fundamentaram sua obra: o materialismo histórico dialético (Freitas, 2000). É aí que está o mérito de seu trabalho. Na pesquisa bibliográfica que empreendeu, procurou nela surpreender a presença ou a ausência dessa fundamentação. Mostrou as diferentes leituras que estão sendo feitas, a partir dos diferentes lugares em que se situam. 0 que critico é que Duarte, ao trazer os vygotskianos brasileiros classificando suas leituras em neo-liberais ou pós-modernas, aprisionou-as em rótulos, cristalizando-as, congelando-as, não construindo um texto dialógico, polifônico. "Encerrando-as nestes limites impediu que estas pudessem se fazer ouvir na pluralidade de sentidos" (Freitas, 2000, p. 25).

Pensando nessa linha dialógica é interessante apontar os trabalhos que trazem outros autores para um profícuo diálogo com Vygotsky. Assim, são importantes as interlocuções com Bakhtin e sua teoria enunciativa de linguagem que esclarecem, ampliam e aprofundam a compreensão da teoria de Vygotsky, visíveis nos textos de Jobim e Souza \& Pereira (1998), Sousa (2000), Pereira (2002), Lemos (2002), Freitas (1998, 1999, 2000, 2000b), Goulart; Kramer (2002) e Vóvio (2000).

Também é dialógico e inovador o trabalho de Gerken (2000), que apresenta algumas idéias fundamentais da rica interlocução que se estabeleceu entre Vygotsky e Lévy-Bruhl, refletindo sobre as repercussões das suas análises no desenvolvimento do modelo teórico da psicologia sócio-histórica de Vygotsky. Parte do pressuposto de que a discussão da relação entre evolução da sociedade e transformação dos modos de representação e de compreensão do mundo, realizada no campo da antropologia, teve um profundo impacto na elaboração do modelo sócio-histórico. Assinala, assim, que Lévy Bruhl elaborou uma rica discussão sobre a natureza da representação coletiva enquanto 
processo de mediação, além de postular a origem social dos processos simbólicos de apreensão da realidade.

Outros trabalhos apontam novos contornos da teoria de Vygotsky a partir das questões postas pela contemporaneidade levando à ressignificação do desenvolvimento infantil, à construção da subjetividade e à mediação de instrumentos culturais como a TV, o computador, a internet. Assim, Jobim e Souza; Pereira (1998), dialogando com Vygotsky e Walter Benjamim, procuram construir uma compreensão da "experiência da infância na contemporaneidade que nos permita uma redefinição do lugar social ocupado pelos sujeitos na imbricada rede de relações inter-subjetivas e sócio-ideológicas que os constituem" (p. 1). Para as autoras, estudar a constituição da subjetividade na infância não se resume em analisar o mundo interno em si mesmo, mas sim em resgatar o reflexo do mundo externo no mundo interno, ou seja, a interação com a realidade. Preocupada também, com a constituição da subjetividade na infância, Lemos (2002) encontra na psicologia sócio-histórica "a possibilidade de estudar a permanente transformação e as contradições que são inerentes aos fenômenos humanos e sociais" (p.1) e baseando-se em Vygotsky e Bakhtin e nas alegorias da literatura, busca compreender, através das narrativas do livro Infância, de Graciliano Ramos (1998), os modos de subjetivação na infância.

$\mathrm{Na}$ esteira de uma ressignificação do desenvolvimento infantil proporcionada pela teoria de Vygotsky, Jobim e Souza; Pereira (2002) apontam o brincar como atividade que constitui a subjetividade infantil, mostrando como a brincadeira emancipa a criança da realidade imediata e reflete suas ações no pensamento por meio da mediação dos significados. Por meio dessa mediação a criança aprende, e é ao aprender que ela se desenvolve. 0 brincar é entendido como uma atividade que se constitui a partir do entrecruzamento da realidade com o imaginário e, a partir da mediação estabelecida, a criança se integra ao real e cria outras realidades.
Também numa reflexão sócio-histórica sobre o brincar, Góes (2001a) analisa situações concretas em creches e pré-escolas, evidenciando como as brincadeiras revelam um funcionamento lúdico-imaginário no qual as crianças, ao recriarem suas vivências matizadas pelo afeto, podem ultrapassar a lógica do real e com a complexificação das brincadeiras chegam a imaginar um plano de ocorrências virtuais que transgridem aquela lógica. Compreende também, de acordo com o referencial sócio-histórico, que os aspectos cognitivos e afetivos implicados no brincar são necessariamente articulados aos processos de linguagem, num vínculo de afetação recíproca. Desse modo, a autora reafirma a crítica à pedagogização do brincar, assim como revela a necessidade de se estudar mais a fundo a riqueza do modo de ser e agir da criança, que não precisa ser subordinado a propósitos de utilidade formativa no sentido instrucional ou normativo. Em outro trabalho (Góes, 2001a), a autora analisa situações de brincadeiras de crianças surdas percebendo, então, como a linguagem participa da construção imaginária pelo componente da linguagem de sinais.

Enfocando também a esfera do simbólico, Padilha (2001) relaciona-o com o desenvolvimento do deficiente mental. Aponta para a possibilidade de superação de alguns aspectos desse desenvolvimento que, do ponto de vista neurológico, anunciam limitações nas esferas do simbólico. Seu trabalho contribui para a compreensão de que o "processo de simbolização seja tomado como fundamental, como essencial, como princípio na elaboração de programas a serem desenvolvidos com os deficientes mentais" (p. 3).

Assim como Lemos (2002) promoveu um diálogo de Vygotsky com a literatura, Shima (2003) estabelece interlocuções entre a psicologia sócio-histórica e as artes plásticas objetivando, num criativo texto, uma maior compreensão do homem contemporâneo. Zorzal; Basso (2001) apresentam os pressupostos para uma perspectiva histórico-cultural 
sobre o tema da criatividade, propondo uma compreensão ontológica da criatividade humana na qual a atividade criativa se desloca do âmbito apenas individual e particular para o âmbito social e histórico. Trabalham nessa perspectiva com um grupo de professores do ensino fundamental utilizando a abordagem de Vygotsky sobre o processo criativo.

Numa outra direção, os trabalhos de Oliveira (1999), Vóvio (2000), Moura (2000) no interior do GT 18, Educação de Pessoas Jovens e Adultos, respaldando-se em Vygotsky e autores vygotskianos, procuram compreender as relações entre cultura e modos de funcionamento cognitivo. Oliveira (1999) parte da idéia de que "a educação de jovens e adultos não remete apenas a uma questão de especificidade etária, mas, primordialmente, a uma questão de especificidade cultural” (p. 59). Mostra a necessidade de historicizar seus sujeitos não os pensando abstratamente e sim compreendendo-os na sua situação de exclusão que define a especificidade de sua situação enquanto aprendizes. Daí a importância da adequação da escola para este público alvo específico, em termos de sua própria organização, currículo, programa e métodos de ensino, visando uma real aprendizagem. A autora encontra na teoria histórico-cultural a forma mais fecunda e não determinista para a compreensão das relações entre cultura e modalidades de pensamento, por postular que o psiquismo se constrói ao longo de sua própria história numa complexa interação entre quatro planos genéticos: a filogênese, a sociogênese, a ontogênese e a microgênese.

Moura (2000) relata um estudo empírico que teve como objetivo identificar possíveis mudanças que ocorrem no pensamento de jovens e adultos em processo de escolarização no âmbito da aprendizagem de um conceito cientifico determinado. Toma como referências teorias que investigam as relações entre diferenças culturais e modos de pensamento (Vygotsky, Luria, Cole, Tulviste e Oliveira), explorando a possibilidade de influên- cias da escolarização nos processos de funcionamento cognitivo. Em seu trabalho conclui que no âmbito da aprendizagem de um determinado conceito científico, emerge um novo tipo de pensamento conceitual baseado em conhecimentos teóricos, desvinculados das experiências pessoais. Vóvio (2000) relata em seu texto uma pesquisa sobre a produção de textos narrativos orais e escritos elaborados por jovens e adultos que iniciaram ou retomaram seus estudos no ensino fundamental supletivo. Seu objetivo foi estudar como jovens e adultos em processo de escolarização elaboram autobiografias orais e escritas, tendo como pano de fundo as conseqüências sociais e individuais do letramento.

As relações entre linguagem, cultura e cognição também são estudadas e pesquisadas por Gerken, que, em seu texto apresentado no GT 20, teve como objetivo discutir alguns problemas teóricos formulados no interior de uma pesquisa que

buscou a compreensão dos processos cognitivos e culturais através dos quais sujeitos pertencentes a culturas fundamentalmente orais se apropriam da linguagem escrita e, no mesmo movimento, tentar apreender quais são as conseqüências culturais e cognitivas desse processo na cultura Xacriabá. (2001, p.1)

Retomando as contribuições mais importantes no cenário contemporâneo da psicologia a respeito da relação entre linguagem, cognição e cultura, Gerken (1999) focaliza mais especificamente, em seu trabalho encomendando para o GT 10, a relação entre oralidade, escrita, cognição e cultura. Consegue articular essas questões no interior dos estudos de outros autores contemporâneos indagando: quais as conseqüências sociais e cognitivas do acesso à escrita? Na profícua interlocução que estabelece com os autores Jerome Bruner, Patrícia Greenfield, S. Scribner e Michael Cole, Davis Olson e Walter Ong, vai articulando seus conceitos, analisando-os, refutando-os, construin- 
do sentidos outros, sugerindo uma ampliação dos conceitos iniciais de Vygotsky sobre essas questões. Não realiza um estudo conclusivo, mas o cruzamento que faz das diferentes perspectivas aponta para uma definição geral do processo de letramento que assim pode ser enunciada:

este processo tanto em sua dimensão social quanto individual é sobredeterminado por processos lingüísticos e culturais definidos pelos contornos da linguagem oral. Por isso, para compreendermos os processos de apropriação cultural ou individual da linguagem escrita, precisamos compreender os processos culturais que ocorrem nas culturas orais. (Geiken, 1999, p. 50)

Outras questões envolvendo o letramento são tratadas num diálogo com Vygotsky e Bakhtin nos textos de Freitas (1998, 1999, 2000a) nos quais se abordam as práticas socioculturais de crianças e adolescentes na contemporaneidade, chegando ao novo letramento digital proporcionado pelo uso da internet.

A interlocução da teoria de Vygotsky com a teoria da atividade a partir de trabalhos de Leontiev e Davidov está presente em dois trabalhos. Libâneo (2003), num trabalho encomendado para o GT 4, Didática, reflete sobre o papel da didática mostrando a escola como lugar de mediação cultural, o que se realiza pelo trabalho dos professores com a aprendizagem escolar, compreendida como um meio pelo qual os alunos adquirem conceitos científicos e desenvolvem suas capacidades operativas. Relaciona esse papel da didática com a teoria histórico-cultural chamando para a discussão Vygotsky e Davidov. Ele articula muito bem seus conhecimentos sobre didática e o papel do professor: mediação docente entre o aluno e o conhecimento para possibilitar condições e meios de aprendizagem. Apropria-se com clareza de como Vygotsky e Davidov são o suporte teórico para a compreensão desse processo, no qual o professor e o conteúdo importam para a aprendizagem e o desenvolvimento cognitivo do aluno. Afirma:

minha tendência é de me apropriar dos aspectos mais substantivos da proposta de Davidov (em conexão com Vygotsky) e agregar a eles outras propostas que podem formar uma visão mais contemporânea e mais plurifacetada dos métodos de ensino em função do desenvolvimento mental dos alunos. (Libâneo, 2003, p.17)

0 autor ainda encontra apoio em Vygotsky e Davidov para criticar o ensino tradicional e enfatizar a importância do desejo e das emoções no processo de aprendizagem. Posso concluir que este autor se apropria da teoria de Vygotsky na sua relação com Davidov e consegue avançar em relação a ela ao considerar que essa teoria do ensino desenvolvimental precisa ser objeto de pesquisa para que ela possa alcançar outras implicações que se impõem hoje ao ensino escolar, como a formação de valores morais e aspectos éticos da existência, as diferenças culturais e o efetivo papel dos grupos nos processos de aprendizagem.

Coerente com essa perspectiva assinalada por Libâneo, Sforni (2003) reflete sobre o desafio que hoje se coloca para os educadores: tornar a escolaridade significativa para o desenvolvimento dos alunos. Ele afirma que

um conhecimento significativo, em nossa concepção, é aquele que se transforma em instrumento cognitivo do aluno, ampliando tanto o conteúdo quanto a forma do seu pensamento. Essa concepção nos aproxima das contribuições teóricas histórico-culturais. Segundo Vygotsky, maior expoente dessa linha teórica, as práticas culturais são constitutivas do psiquismo. 0 ensino formal faz parte dessa cultura, portanto, também contribui para a formação dos sujeitos. (Sforni, 2003, p. 2)

Compreende que a escola exerce um papel essencial na possibilidade de inserção do homem na coletividade como cidadão pleno, 
sendo ela considerada a maior responsável pela construção de bases para o desenvolvimento psíquico. Indicando que Vygotsky na escolarização dedica uma especial atenção aos conceitos científicos indaga: "como a aprendizagem de conceitos científicos - ênfase do ensino - pode concorrer para o desenvolvimento psíquico? Em que sentido a organização do ensino pode influenciar qualitativamente esse processo?" ( Sforni, 2003, p. 3). Apesar de considerar importante a contribuição de Vygotsky para subsidiar as respostas a essas questões, está consciente de que o autor, acerca do desenvolvimento dos conceitos, não realizou prescrições práticas e por isso busca apoio nos partidários da teoria da atividade como Leontiev, Elkonin, Galperin e principalmente Davidov. Estes autores ajudam a pensar que um ensino promotor do desenvolvimento implica analisar a qualidade do conteúdo escolar e o modo de sua apropriação pelo aluno. Está preocupada em pesquisar e estudar como esses dois aspectos em conjunto podem trazer elementos orientadores para a organização do ensino

\section{Tecendo algumas reflexões a partir do trabalho empreendido}

No desenvolvimento de todo esse trabalho fui refletindo sobre o que os dados podem dizer sobre a apropriação de Vygotsky na educação, a partir da produção apresentada na ANPEd de 1998 a 2003. A compreensão que construí se articula com questões por mim levantadas há doze anos e que transportei para o início deste texto: 0 que aconteceu nesse espaço de tempo? Até que ponto as perguntas então levantadas estão sendo respondidas e as prospecções feitas estão se concretizando?

Considero que houve um aumento da divulgação das idéias do autor, como o demonstram os 87 trabalhos apresentados nesses seis anos de reuniões da ANPEd. Os 8,31\% de textos marcados pela presença de Vygotsky possibilitam compreender a importância que seu pensamento representa ainda hoje para a educação. Muitas das questões que os educadores levantam e discutem estão encontrando respaldo nos conceitos vygotskianos. A reflexão dessas questões à luz desse referencial teórico pode contribuir tanto para uma apropriação revigorada da própria teoria quanto para um avanço substantivo e produtivo no plano pedagógico. Revigoramento e avanços possíveis a partir de um Vygotsky estudado com um maior conhecimento de sua obra como um todo, o que agora é possível, pelo esforço de divulgação e o aumento de traduções, que geraram a publicação de um número maior de seus textos. Nos cursos de graduação que formam professores e nos programas de pós-graduação das áreas das ciências humanas, nos quais sua teoria tem sido estudada, é importante a atenção para um trabalho em profundidade para que se atenuem os problemas das apropriações superficiais ou desarticuladas. Educadores, especialistas em Vygotsky, podemos e devemos trabalhar neste nível potencial do conhecimento para elevá-lo, pelo esforço dos trabalhos em sala de aula e através de nossas pesquisas e publicações, a um desenvolvimento real. Temos um compromisso nesse sentido. Percebe-se, pela incidência com que o tema foi abordado, que o conceito de aprendizagem de Vygotsky é o que tem grandes repercussões hoje para o trabalho do professor. Mas ele não pode ser apreendido desvinculado da concepção de desenvolvimento de Vygotsky que integra o natural e o cultural. Desse ponto de partida é que se apresentam as questões da mediação e da relação linguagem-pensamento que se refletem na formação dos conceitos, para uma melhor compreensão da relação da aprendizagem com o desenvolvimento, ponto focal do fazer do professor.

Posso perceber que isto é sentido hoje até por professores não vinculados especificamente às questões da Psicologia da Educação. Enquanto até agora o grande esforço do estudo e divulgação de Vygotsky estava concentrado naqueles que de alguma forma trabalham 
com a Psicologia da Educação ou com as questões da linguagem e da Educação Especial, vejo despontar na $26^{\text {a }}$ reunião um trabalho encomendado de um especialista da Didática (Libâneo, 2003), que aponta como necessário o reconhecimento da teoria de Vygotsky para o ensino e aprendizagem, chamando a atenção para sua abordagem da aprendizagem, formação de conceitos e valorização dos conteúdos escolares.

Na mesma linha de idéias, no GT 13, Educação Fundamental, a discussão das questões da aprendizagem num diálogo com os princípios da teoria da atividade começa a surgir em 2003 (Sforni, 2003). Nos GTs 4, 8, 10, que focalizam especificamente o professor, estáse, pois, começando a se construir um conhecimento com a preocupação do aproveitamento das idéias de Vygotsky e de autores sócio-históricos na formação do professor que precisa ser intensificado e continuado. Isso é promissor e sinal de uma expansão da teoria. Está havendo uma compreensão da necessidade dela por parte de educadores, não restrita apenas ao âmbito da Psicologia da Educação.

Por outro lado, também no GT 20, Psicologia da Educação, está presente essa preocupação com a formação do professor como bem o ilustra um dos trabalhos apresentados (Meira, 2000). A autora reflete sobre a necessidade de redefinição do papel da psicologia na formação docente, procurando que isso aconteça de uma forma crítica que leve a um movimento transformador. Nesse sentido a psicologia de Vygotsky, ao apontar para a natureza sócio-histórica da subjetividade humana e mostrar os fenômenos enquanto mediações entre a história social e a vida concreta dos indivíduos, pode contribuir para a redefinição do papel da psicologia na formação docente de modo a viabilizar que os conhecimentos psicológicos possam contribuir efetivamente para a elaboração de propostas pedagógicas mais consistentes que resultem em melhorias da prática docente e do próprio ensino e da aprendizagem. Para tal, mostra a necessidade de um envolvimento mais rigoroso com a construção de um corpo de conhecimentos teórico-críticos que possa constituir-se em uma mediação fundamental entre as finalidades transformadoras e as práticas da psicologia escolar.

Nesse sentido, percebo que as discussões do GT de Psicologia da Educação estão levantando com muita propriedade a necessidade de aprofundamento na teoria a partir de seus fundamentos. Apontam a preocupação com apropriações de Vygotsky a-históricas e a necessidade de se ir de fato aos seus fundamentos de base, construídos a partir do materialismo histórico-dialético, daí a necessidade de compreender Vygotsky em sua historicidade (Duarte 2000, Freitas 2000, Pino 1999, Tuleski, 2000).

No GT 15 de Educação Especial se está também construindo uma reflexão séria e inovadora aproveitando o conhecimento de Vygotsky sobre a deficiência para uma compreensão dos trabalhos da área que se refletem no plano pedagógico. No GT 07 , Educação de Crianças de 0 a 6 anos, por sua vez, a ressignificação da noção de desenvolvimento e a compreensão do papel das brincadeiras e jogos no desenvolvimento, a partir dos trabalhos de Vygotsky, estão possibilitando uma nova compreensão da criança na contemporaneidade, abrindo perspectivas para uma ação educativa transformadora nas instituições que trabalham com a educação infantil.

Assim, percebo que este trabalho está chegando ao seu final embora muitas questões ainda pudessem ser abertas. Foi importante realizá-lo e ao me reportar a algumas considerações feitas, na minha pesquisa com educadores vygotskianos em 1992, encontro algumas relações interessantes. Em resposta à minha pergunta (Freitas, 1994) quanto às prospecções que se faziam, naquele momento, a respeito do desenvolvimento da teoria psicológica sóciohistórica no Brasil, encontrei respostas que apontavam para a evolução que a teoria teria 
porque estava sendo estudada e pesquisada por pessoas preocupadas com o seu desenvolvimento. Assinalavam ainda que estas pessoas estavam formando um grupo, não fechado mas aberto a trocas, a uma construção coletiva. Coerentemente com os princípios do enfoque teórico, a construção da apropriação brasileira de Vygotsky estava se fazendo coletivamente. E esse movimento coletivo continua, pois, através dos textos agora analisados, pude perceber a presença forte do grupo inicial e de novos estudiosos que surgiram a partir dele, por meio de um contato direto como alunos e orientandos ou um contato mediado por sua produção existente em livros, artigos e trabalhos publicados. É interessante como há um cruzamento de vozes, de autores, nos textos analisados. É o grupo crescendo, mas continuando a desenvolver uma construção compartilhada de conhecimento.

Diziam ainda, os professores por mim entrevistados, que os discursos do grupo inicial poderiam se espraiar dando origem a outras ramificações ou transformações. Assinalavam que, naquele momento (1992), a relação com a perspectiva sócio-histórica estava ainda circunscrita à leitura dos teóricos com a respectiva incorporação conceitual. Começavam a aparecer as indagações decorrentes das leituras e daquilo que nelas não se encontrava, anunciando o início de uma expansão conceitual que ainda estaria para acontecer.

Ao finalizar este trabalho, vejo que essas palavras se cumpriram de alguma maneira. Os estudos avançaram, as leituras se estenderam, as perguntas se multiplicaram e novos contornos foram se organizando em novas leituras de Vygotsky. Leituras diversas, múltiplas. Mas o que é ler? Bakhtin ensina que ler é construir sentidos num diálogo do leitor com o autor. Diálogo esse no qual o leitor apreende a outra voz a partir do lugar em que se situa, de seus presumidos. Assim, surgem essas diferentes leituras de diferentes leitores e o autor não é mais o senhor de seu texto. Como diz Geraldi:
Humanos, estamos condenados a significar, incluindo neste significar também nossas entonações pelas quais revelamos avaliações e juízos de valor expressos a cada momento irrepetível e único da vida. (...) Fazer ciência é essencialmente construir significados, cuja validade ou rigor - ao contrário do que imaginávamos até meados do século $X X$ - somente se calcula no horizonte próprio da teoria em que os significados foram construídos. (...) Mas como manter este rigor se dispomos apenas de palavras com que construir significados? Renunciando às enunciações para deter os sentidos dos enunciados, para fixar-lhes sentidos sempre recuperáveis rigorosamente segundo um horizonte teórico específico? Aceitar uma tal renúncia é também aceitar mutilar as já pobres palavras de que dispomos, tornando-as elementos de um código biunívoco. Parece que não é assim que a linguagem funciona: se seus elementos estruturais têm vocação para reaparecerem, o acontecimento ou acaso de seu reaparecimento demanda sempre a correlação entre o que se repete com as condições de sua emergência. Os sentidos são sempre produtos de cálculos, e ao jogo das compreensões, os sujeitos comparecem carregados de interpretantes, carregados de palavras, carregados de contrapalavras, enfim, carregados de histórias. (Geraldi, 2003, p. 2, 3)

Assim, no que se refere a obra de Vygotsky e suas apropriações no Brasil, em relação aos trabalhos produzidos nos GTs da ANPEd de 1998 a 2001, a fazer a minha leitura dos textos e apreender neles a leitura que fazem de Vygotsky, parti da compreensão que contrapor leituras é uma forma de diálogo, no qual se torna evidente que há outras leituras possíveis. A mim parece que mais do que corrigir leituras (como se houvesse apenas uma leitura dos conceitos elaborados na área das ciências humanas), importa contrapor diferentes leituras deixando emergir as contradições, o embate das idéias.

Esta é uma sugestão que também Geraldi nos dá para um caminho a ser toma- 
do: reconhecer as condições de produção do autor e seus textos, mas sem se colocar no lugar de quem está pondo as coisas em ordem. As leituras podem ser rigorosas, mas é uma pretensão colocar as coisas nos devidos lugares. 0 importante é registrar esse movimento de dife- rentes vozes e leituras que mostram como hoje, na grande temporalidade, a obra de Vygotsky continua viva e mais intensa do que no tempo de sua gestação, porque está sendo vitalizada pelos diálogos e contra-palavras que provocam entre os estudiosos contemporâneos.

\section{ANEXO}

Tabela1: Síntese geral dos dados por reuniões da ANPEd

\begin{tabular}{|c|c|c|c|c|c|c|}
\hline \multirow[t]{3}{*}{ Ano } & \multirow{3}{*}{$\begin{array}{c}\text { Reuniões } \\
\text { Anped }\end{array}$} & \multicolumn{5}{|c|}{ Total } \\
\hline & & \multicolumn{5}{|c|}{ Pôsteres (P) } \\
\hline & & $\mathbf{N}^{0}$ & $\mathbf{S}$ & $\%$ & $\mathbf{N}$ & $\%$ \\
\hline 1998 & $21^{a}$ & 49 & 1 & 2,04 & 48 & 97,96 \\
\hline 1999 & $22^{\mathrm{a}}$ & 60 & 3 & 5,00 & 57 & 95,00 \\
\hline 2000 & $23^{a}$ & 49 & 1 & 2,04 & 48 & 97,96 \\
\hline 2001 & $24^{a}$ & 56 & 3 & 5,36 & 53 & 94,64 \\
\hline 2002 & $25^{a}$ & 44 & 4 & 9,09 & 40 & 90,91 \\
\hline \multirow[t]{2}{*}{2003} & $26^{a}$ & 34 & 2 & 5,88 & 33 & 97,06 \\
\hline & Total por Reunião & 292 & 14 & 4,79 & 279 & 95,55 \\
\hline
\end{tabular}

\begin{tabular}{|c|c|c|c|c|c|c|}
\hline \multirow[t]{3}{*}{ Ano } & \multirow{3}{*}{$\begin{array}{c}\text { Reuniões } \\
\text { Anped }\end{array}$} & \multicolumn{5}{|c|}{ Total } \\
\hline & & \multicolumn{5}{|c|}{ Trabalhos Encomendados (TE) } \\
\hline & & $\mathbf{N}^{0}$ & $\mathbf{S}$ & $\%$ & $\mathbf{N}$ & $\%$ \\
\hline 1998 & $21^{a}$ & 15 & 0 & 0,00 & 15 & 100,00 \\
\hline 1999 & $22^{a}$ & 11 & 5 & 45,45 & 6 & 54,55 \\
\hline 2000 & $23^{a}$ & 10 & 1 & 10,00 & 9 & 90,00 \\
\hline 2001 & $24^{a}$ & 11 & 1 & 9,09 & 10 & 90,91 \\
\hline 2002 & $25^{\mathrm{a}}$ & 17 & 2 & 11,76 & 15 & 88,24 \\
\hline \multirow[t]{2}{*}{2003} & $26^{a}$ & 17 & 1 & 5,88 & 16 & 94,12 \\
\hline & $\begin{array}{l}\text { Total por } \\
\text { Reunião }\end{array}$ & 81 & 10 & 12,35 & 71 & 87,65 \\
\hline
\end{tabular}

\begin{tabular}{|c|c|c|c|c|c|c|}
\hline \multirow{2}{*}{ Ano } & \multirow{2}{*}{$\begin{array}{c}\text { Reuniões } \\
\text { Anped }\end{array}$} & \multicolumn{5}{|c|}{ Total } \\
\cline { 3 - 7 } & & \multicolumn{5}{|c|}{ Trabalhos Apresentados (TA) } \\
\hline & & $\mathbf{N}^{0}$ & $\mathbf{S}$ & $\mathbf{\%}$ & $\mathbf{N}$ & $\mathbf{\%}$ \\
\hline $\mathbf{1 9 9 8}$ & $\mathbf{2 1}^{\text {a }}$ & 105 & 9 & 8,57 & 96 & 91,43 \\
\hline $\mathbf{1 9 9 9}$ & $\mathbf{2 2}^{\text {a }}$ & 136 & 8 & 5,88 & 128 & 94,12 \\
\hline $\mathbf{2 0 0 0}$ & $\mathbf{2 3}^{\text {a }}$ & 108 & 21 & 19,44 & 87 & 80,56 \\
\hline $\mathbf{2 0 0 1}$ & $\mathbf{2 4}^{\text {a }}$ & 110 & 11 & 10,00 & 99 & 90,00 \\
\hline $\mathbf{2 0 0 2}$ & $\mathbf{2 5}^{\text {a }}$ & 94 & 3 & 3,19 & 91 & 96,81 \\
\hline $\mathbf{2 0 0 3}$ & $\mathbf{2 6}^{\mathbf{a}}$ & 121 & 11 & 9,09 & 110 & 90,91 \\
\hline & Total por Reunião & & & $\mathbf{6 7}$ & & \\
\cline { 3 - 7 } & & $\mathbf{6 7 4}$ & $\mathbf{6 3}$ & $\mathbf{9 , 3 5}$ & $\mathbf{6 1 1}$ & $\mathbf{9 0 , 6 5}$ \\
\hline
\end{tabular}

\begin{tabular}{|c|c|c|c|c|c|c|}
\hline \multirow[t]{2}{*}{ Ano } & \multirow{2}{*}{$\begin{array}{c}\text { Reuniões } \\
\text { Anped }\end{array}$} & \multicolumn{5}{|c|}{ Total Geral por Reuniões } \\
\hline & & $\mathbf{N}^{\mathbf{0}}$ & $\mathbf{S}$ & $\%$ & $\mathbf{N}$ & $\%$ \\
\hline 1998 & $21^{\mathrm{a}}$ & 169 & 10 & 5,92 & 159 & 94,08 \\
\hline 1999 & $22^{\mathrm{a}}$ & 207 & 16 & 7,73 & 191 & 92,27 \\
\hline 2000 & $23^{a}$ & 167 & 23 & 13,77 & 144 & 86,23 \\
\hline 2001 & $24^{a}$ & 177 & 15 & 8,47 & 162 & 91,53 \\
\hline 2002 & $25^{\mathrm{a}}$ & 155 & 9 & 5,81 & 146 & 94,19 \\
\hline 2003 & $26^{\mathrm{a}}$ & 172 & 14 & 8,14 & 159 & 92,44 \\
\hline & Total Geral & 1047 & 87 & 8,31 & 961 & 91,79 \\
\hline
\end{tabular}

\begin{tabular}{|c|c|c|c|c|c|}
\hline \multirow[t]{2}{*}{ Modalidades } & \multicolumn{5}{|c|}{ Total geral } \\
\hline & $\mathbf{N}^{0}$ & $\mathbf{S}$ & $\%$ & $\mathbf{N}$ & $\%$ \\
\hline $\mathbf{P}$ & 292 & 14 & 4,79 & 279 & 95,55 \\
\hline TE & 81 & 10 & 12,35 & 71 & 87,65 \\
\hline TA & 674 & 63 & 9,35 & 611 & 90,65 \\
\hline Totais & 1047 & 87 & 8,31 & 961 & 91,79 \\
\hline
\end{tabular}

LEGENDA :
$N^{\circ}$ : Número de Textos
P: Pôsteres
S : SIM = Presença de Vygotsky
TE: Trabalhos Encomendados
$N$ : NÃO = Não referência à Vygotsky TA: Trabalhos Apresentados 
Tabela 2: Presença de Vygotsky por GT nas reuniões da ANPEd.

\begin{tabular}{|c|c|c|c|}
\hline \multicolumn{4}{|c|}{ GT 4 - Didática } \\
\hline \multicolumn{4}{|c|}{ Total por GT } \\
\hline & & $\mathbf{S}$ & $\mathbf{\%}$ \\
\hline P & 30 & 2 & 6,67 \\
\hline TE & 9 & 1 & 11,11 \\
\hline TA & 59 & 1 & 1,69 \\
\hline Total & $\mathbf{9 8}$ & $\mathbf{4}$ & $\mathbf{4 , 0 8}$ \\
\hline
\end{tabular}

\begin{tabular}{|c|c|c|c|}
\hline \multicolumn{4}{|c|}{ GT 7 - Educação de crianças de $\mathbf{0}$ a $\mathbf{6}$ anos } \\
\hline \multicolumn{4}{|c|}{ Total por $\mathbf{~ G T}$} \\
\hline & & $\mathbf{S}$ & $\mathbf{\%}$ \\
\hline P & 31 & 2 & 6,45 \\
\hline TE & 9 & 1 & 11,11 \\
\hline TA & 62 & 6 & 9,68 \\
\hline Total & $\mathbf{1 0 2}$ & $\mathbf{9}$ & $\mathbf{8 , 8 2}$ \\
\hline
\end{tabular}

\begin{tabular}{|c|c|c|c|}
\hline \multicolumn{5}{|c|}{ GT 8 - Formação de Professores } \\
\hline \multicolumn{4}{|c|}{ Total por GT } \\
\hline & & S & \% \\
\hline P & 54 & 2 & 3,70 \\
\hline TE & 6 & 0 & 0,00 \\
\hline TA & 83 & 2 & 2,41 \\
\hline Total & $\mathbf{1 4 3}$ & $\mathbf{4}$ & $\mathbf{2 , 8 0}$ \\
\hline
\end{tabular}

\begin{tabular}{|c|c|c|c|}
\hline \multicolumn{4}{|c|}{ GT 10 - Alfabetização, Leitura e Escrita } \\
\hline \multicolumn{4}{|c|}{ Total por GT } \\
\hline & & S & \% \\
\hline P & 22 & 3 & 13,64 \\
\hline TE & 9 & 2 & 22,22 \\
\hline TA & 77 & 12 & 15,58 \\
\hline Total & $\mathbf{1 0 8}$ & $\mathbf{1 7}$ & $\mathbf{1 5 , 7 4}$ \\
\hline
\end{tabular}

\begin{tabular}{|c|c|c|c|}
\hline \multicolumn{5}{|c|}{ GT 13 - Educação Fundamental } \\
\hline \multicolumn{4}{|c|}{ Total por GT } \\
\hline & & $\mathbf{S}$ & $\%$ \\
\hline P & 35 & 0 & 0,00 \\
\hline TE & 8 & 0 & 0,00 \\
\hline TA & 62 & 5 & 8,06 \\
\hline Total & $\mathbf{1 0 5}$ & $\mathbf{5}$ & $\mathbf{4 , 7 6}$ \\
\hline
\end{tabular}

\begin{tabular}{|c|c|c|c|}
\hline \multicolumn{4}{|c|}{ GT 15 - Educação Especial } \\
\hline \multicolumn{4}{|c|}{ Total por GT } \\
\hline & & $\mathbf{S}$ & $\mathbf{\%}$ \\
\hline P & 17 & 1 & 5,88 \\
\hline TE & 12 & 2 & 16,67 \\
\hline TA & 67 & 10 & 14,93 \\
\hline Total & $\mathbf{9 6}$ & $\mathbf{1 3}$ & $\mathbf{1 3 , 5 4}$ \\
\hline
\end{tabular}

\begin{tabular}{|c|c|c|c|}
\hline \multicolumn{4}{|c|}{ GT 16 - Educação e Comunicação } \\
\hline \multicolumn{4}{|c|}{ Total por GT } \\
\hline & & $\mathbf{S}$ & $\mathbf{\%}$ \\
\hline P & 32 & 1 & 3,13 \\
\hline TE & 6 & 0 & 0,00 \\
\hline TA & 78 & 1 & 1,28 \\
\hline Total & $\mathbf{1 1 6}$ & $\mathbf{2}$ & $\mathbf{1 , 7 2}$ \\
\hline
\end{tabular}

\begin{tabular}{|c|c|c|c|}
\hline \multicolumn{4}{|c|}{ GT 18 - Educação de Pessoas Jovens e Adultas } \\
\hline \multicolumn{4}{|c|}{ Tor GT } \\
\hline & & S & \% \\
\hline P & 25 & 1 & 4,00 \\
\hline TE & 8 & 1 & 12,50 \\
\hline TA & 60 & 5 & 8,33 \\
\hline Total & $\mathbf{9 3}$ & $\mathbf{7}$ & $\mathbf{7 , 5 3}$ \\
\hline
\end{tabular}

\begin{tabular}{|c|c|c|c|}
\hline \multicolumn{5}{|c|}{ GT 19 - Educação Matemática } \\
\hline \multicolumn{4}{|c|}{ Total por GT } \\
\hline & & $\mathbf{S}$ & $\mathbf{\%}$ \\
\hline P & 10 & 0 & 0,00 \\
\hline TE & 2 & 0 & 0,00 \\
\hline TA & 63 & 6 & 9,52 \\
\hline Total & $\mathbf{7 5}$ & $\mathbf{6}$ & $\mathbf{8 , 0 0}$ \\
\hline
\end{tabular}

\begin{tabular}{|c|c|c|c|}
\hline \multicolumn{4}{|c|}{ GT 20 - Psicologia da Educação } \\
\hline \multicolumn{4}{|c|}{ Total por GT } \\
\hline & & S & $\%$ \\
\hline P & 36 & 2 & 5,56 \\
\hline TE & 12 & 3 & 25,00 \\
\hline TA & 63 & 15 & 23,81 \\
\hline Total & $\mathbf{1 1 1}$ & $\mathbf{2 0}$ & $\mathbf{1 8 , 0 2}$ \\
\hline
\end{tabular}




\section{Referências bibliográficas}

BAKHTIN, M. Marxismo e filosofia da linguagem. São Paulo: Hucitec, 1988.

BAQUERO, R. Vygotsky e a aprendizagem escolar. Porto Alegre: Artmed, 1998.

BEZERRA, P. Prefácio. In: VIGOTSKI, L. S A construção do pensamento e da linguagem. S. Paulo: Martins Fontes, 2001.

BRUNER, J. Prologue to the english edition. In: VYGOTSKY, L. S. Problems of general psychology. New York: Plenum Press, 1987.

CHAIKLIN, Seth. Developmental teaching in upper-secondary scholl. [S.I.: s.n.], 2003. Disponível em: <http://www.maro.newmail.ru>. Acesso em: 10 fev. 2003.

DANIELS, H. Vygotsky em foco: pressupostos e desdobramentos. São Paulo: Papirus, 1994.

DAVIS, C.; SILVA, M.; ESPÓSITO, Y. Papel e valor das interações sociais na sala de aula. Cadernos de Pesquisa. São Paulo, n. 71, p. 49-54, 1989.

DAVÍDOV, V. La enseñanza escolar y el desarrollo psíquico. Moscu: Editorial Progreso, 1988.

Tipos de generalización en la enseñanza. Habana: Editorial Pueblo y Educación. 1982.

DAVÍDOV, V.; ZINCHENKO, V. P. A contribuição de Vygotsky para desenvolvimento da Psicologia. In: DANIELS, H. Vygotsky em foco: pressupostos e desdobramentos. São Paulo: Papirus, 1994, p.151-168.

DUARTE, N. Educação escolar, teoria do cotidiano e a escola de Vygotski. Campinas: Autores Associados, 1996.

Vygotski e o "aprender a aprender": crítica às apropriações neoliberais e pós-modernas da teoria vygotskiana. Campinas: Autores Associados, 2000.

FONTANA, R. A. C. Trabalho e subjetividade: nos rituais da iniciação, a constituição do ser professora. Cadernos CEDES, Campinas. n. 50 , p. 103-118, 2000.

FREITAS, M. T.A. Psicologia e educação: um intertexto. 1992. Tese (Doutorado) - Departamento de Educação, PUC, Rio de Janeiro, 1992. 0 pensamento de Vygotsky e Bakhtin no Brasil. Campinas: Papirus, 1994.

Psicologia e educação: um intertexto. São Paulo: Ática, 1994b.

. Compreendendo práticas contemporâneas de leitura e escrita. In: REUNIÃO ANUAL DA ANPEd, 21, 1998, Caxambu. Anais... Caxambu, ANPEd, 1998. 1CD-ROM.

. No discurso de adolescentes, as práticas de leitura e escrita na escola. In: REUNIÃO ANUAL DA ANPEd, 22, 1999, Caxambu. Anais... Caxambu, ANPEd, 1999. 1CD-ROM. 2000.

. As apropriações do pensamento de Vygotsky no Brasil: um tema em debate. Psicologia e Educação. São Paulo, p. 9-28,

. Escrita teclada: uma nova forma de escrever? In: REUNIÃO ANUAL DA ANPEd, 23., 1998, Caxambu. Anais... Caxambu, ANPEd, 2000b. 1CD-ROM.

GARCIA, C; CASTRO, L. R.; JOBIM e SOUZA, S. (Orgs) Infância, cinema e sociedade. Rio de Janeiro: Ravil, 1997.

GERALDI, J. W. É possível investir nas enunciações, sem as garantias, dos enunciados já firmados? In: SEMINÁRIO DE PESQUISA D0 PPGE/UFF, 3., Educação e poder: tensões de um país em mudança. Niterói: UFF, 03 set. 2003.

GERKEN, C. H. S. A razão e o outro em Lévy-Bruhl: notas para estudo de um diálogo com a psicologia sócio-histórica de Vygotsky. In: REUNIÃO ANUAL DA ANPEd, 23., 2000, Caxambu. Anais... Caxambu, ANPEd, 2000. 1CD-ROM. 
Escolarização e apropriação da escrita nas aldeias Xacribá: elementos da teoria psicológica necessária. In: REUNIÃO ANUAL DA ANPEd, 24., 2001, Caxambu. Anais... Caxambu, ANPEd, 2001. 1CD-ROM.

Equação oralidade e escrita na psicologia: soluções contemporâneas. In: REUNIÃO ANUAL DA ANPEd, 22., 1999, Caxambú. Anais... Caxambu, ANPEd, 1999. 1CD-ROM.

GÓES, M. C. R. 0 jogo imaginário na infância: a linguagem e a criação. In: REUNIÃO ANUAL DA ANPEd, 23., 2000a, Caxambú. Anais... Caxambu, ANPEd, 2000. 1CD-ROM.

0 brincar de crianças surdas: examinando a linguagem no jogo imaginário. In: REUNIÃO ANUAL DA ANPEd, 24., 2001a, Caxambú. Anais... Caxambu, ANPEd, 2001. 1CD-ROM.

A abordagem microgenética na matriz histórico-cultural: uma perspectiva para o estudo da constituição da subjetividade. Caderno CEDES, Campinas, n. 50, p.9-25, 2000 b.

A construção de conhecimentos e o conceito de zona de desenvolvimento proximal. In: MORTIMER, E. F; SMOLKA, A. L (Orgs) Linguagem, cultura e cognição. Belo-Horizonte: Autêntica, 2001 b.

A natureza social do desenvolvimento psicológico. Cadernos CEDES, São Paulo, n. 24, p.65-78, 1991.

GOULART, C.; KRAMER, S. Alfabetização, leitura, escrita: 25 anos da ANPEd e 100 anos de Drummond. Revista Brasileira de Educação, São Paulo, n. 21. p.127-146,set/out/nov/dez. 2002.

JOBIM e SOUZA, S. Infância e linguagem-Bakhtin, Vygotsky e Benjamin. Campinas: Papirus, 1994.

. Re-significando a psicologia do desenvolvimento: uma contribuição crítica à pesquisa da infância. In: KRAMER, S.; LEITE, M. I. (Orgs) Infância: fios e desafios da pesquisa. Campinas: Papirus,1996. p. 39-56.

JOBIM e SOUZA, S.; PEREIRA, R. M. R. Infância, conhecimento e contemporaneidade. In: REUNIÃO ANUAL DA ANPEd, 21., 1998, Caxambu. Anais... Caxambu: ANPEd, 1998. 1CD-ROM.

KOZULIN, A. 0 conceito de atividade na psicologia soviética: Vygotsky, seus discípulos, seus críticos. In: DANIELS, H. (Org.). Uma introdução da Vygotsky, São Paulo: Loyola, 2002. 111-138.

KRAMER, S. Por entre as pedras: arma e sonho na escola. São Paulo: Ática, 1993.

KRAMER, S.; LEITE, M. I. (Orgs.) Infância e produção cultural. Campinas: Papirus, 1998.

LEMOS, T. V. Nas palavras do escritor: um ensaio sobre a constituição da subjetividade na infância. In: REUNIÃO ANUAL DA ANPEd, 25., 2002, Caxambú. Anais... Caxambu: ANPEd, 2002. 1CD-ROM.

LEONTIEV, A. O desenvolvimento do psiquismo. Lisboa: Livros Horizonte,1978.

LIBÂNEO, J. C. A didática e a aprendizagem do pensar e do aprender: Davidov e a teoria histórico-cultural da atividade. In: REUNIÃO ANUAL DA ANPEd, 26., 2003, Poços de Caldas. Anais... Poços de Caldas: ANPEd, 2003. Disponível em: <http:// www.anped.org.br>.

LURIA,A. R. Desenvolvimento cognitivo: seus fundamentos culturais e sociais. São Paulo: İcone,1990.

Pensamento e linguagem: as últimas conferências de Luria. Porto Alegre: Artmed,1986.

MEIRA, M. E. M. 0 pensamento crítico em psicologia da educação: algumas contribuições da pedagogia hitórico-crítica e da psicologia histórico-cultural. In: REUNIĨ̃ ANUAL DA ANPEd, 23., 2000, Caxambú. Anais... Caxambu: ANPEd, 2000. 1CD-ROM.

MOLL, L. Vygotsky e a educação: implicações a pedagógicas da psicologia sócio-histórica. Porto Alegre: Artmed,1996.

MOURA, M. P. Desenvolvimento do pensamento: um estudo sobre formação de conceitos com jovens e adultos em processo de escolarização. In: REUNIÃO ANUAL DA ANPEd, 23., 2000, Caxambú. Anais... Caxambu: ANPEd, 2000. 1CD-ROM. 
MOYSĖS, L. Aplicações de Vygotsky à educação matemática. Campinas: Papirus, 1997.

OLIVEIRA, M. C. K. Jovens e adultos como sujeitos de conhecimento e aprendizagem. Revista Brasileira de Educação. São Paulo, n. 12, p. 59-73, set/out/nov/dez. 1999.

0 pensamento de Vygotsky como fonte de reflexão sobre a educação. Cadernos Cedes, Campinas, n. 35, p. 9-14, 1995. Vygotsky: aprendizado e desenvolvimento, um processo sócio-histórico. São Paulo: Scipione,1993.

OLIVEIRA, Z.(Org.) Educação infantil: muitos olhares. São Paulo: Cortez,1994.

. Interações sociais e desenvolvimento: a perspectiva sócio-histórica. Cadernos Cedes, Campinas, n. 35, p. 51-64, 1995.

PADILHA,A. M. L. Práticas educativas: perspectivas que se abrem para a Educação Especial. Educação e Sociedade, Campinas, n. 71, p. 197-220, 2000. Número especial.

. A constituição do sujeito simbólico: para além dos limites impostos à deficiência mental. In: REUNIÃO ANUAL DA ANPEd, 23., 2000, Caxambú. Anais... Caxambu: ANPEd, 2000. 1CD-ROM.

PEREIRA, A. P. M. S. 0 processo de aprendizagem através das práticas discursivas em uma classe de aceleração da aprendizagem. In: REUNIÃO ANUAL DA ANPEd, 25., 2002, Caxambú. Anais... Caxambu: ANPEd, 2002. 1CD-ROM.

PINO, A. A psicologia concreta de Vigotski: implicações para a educação. In: REUNIÃO ANUAL DA ANPEd, 22., 1999, Caxambu. Anais... Caxambu, ANPEd, 1999. 1CD-ROM. especial.

0 social e 0 cultural na obra de Lev. S. Vigotski. Educação e Sociedade. Campinas, n. 71, p. 45-78, 2000. Número

RAMOS, G. Infância. Rio de Janeiro: Record, 1998.

REY, F. G. Sujeito e subjetividade. São Paulo: Thomson, 2003.

RIVIÉRE, A. La psicologia de Vygotsky. Madrid: Visor, 1985.

ROJO, R. Enunciação e interação na ZDP: do nonsense à construção dos gêneros de discurso. In: MORTIMER, E F; SMOLKA, A.

L. (Orgs) Linguagem, cultura e cognição. Belo Horizonte: Autêntica, 2001.

SFORNI, M. S. F. Aprendizagem conceitual e organização do ensino: contribuições da teoria da atividade. In: REUNIÃO ANUAL DA ANPEd, 26., 2003, Poços de Caldas. Anais... Poços de Caldas: ANPEd, 2003. 1CD-ROM.

SHIMA, S. M. B. Psicologia educacional e a arte: desvendando o homem contemporâneo. In: REUNIÃO ANUAL DA ANPEd, 26., 2003, Poços de Caldas. Anais... Poços de Caldas: ANPEd, 2003. 1CD-ROM.

SMOLKA, A. L. B. A criança na fase inicial da escrita: alfabetização como um processo discursivo. São Paulo: Cortez,1988. . A prática discursiva na sala de aula: uma perspectiva teórica e um esboço de análise. Cadernos CEDES, São Paulo, n. 24, p. 51-65, 1991. 1995.

Conhecimento e produção de sentidos na escola: a linguagem em foco. Cadernos CEDES, São Paulo, n. 35, p. 41-49,

SMOLKA, A. L. B; GOÉS, M. C. (Org.) A linguagem e o outro no espaço escolar. Vygotsky e a construção do conhecimento. Campinas: Papirus, 1993.

SMOLKA, A. L. B.; GÓES, M. C. R.; PINO, A. A constituição do sujeito: uma questão recorrente? In: WERTSCH, J. V. et al. Estudos socio-culturais da mente. Porto Alegre: ARTMED, 1998. p.143 -160.

SOUSA, C. A. D. Tornando-se professor. In: REUNIÃO ANUAL DA ANPEd, 23, 2000, Caxambu. Anais... Caxambu: ANPEd, 2000. 1CD-ROM. 
TULESKI, S. C. Para ler Vygotsky: recuperando a historicidade perdida. In: REUNIÃO ANUAL DA ANPEd, 23., 2000, Caxambu. Anais... Caxambu: ANPEd, 2000. 1CD-ROM.

TULVISTE, P. Cultural-historical development of verbal thin inking: a psychological study. New York: Nova Science, 1991.

VAN DER VEER, R.; VALSINER, J. Vygotsky: uma síntese. São Paulo: Loyola, 1996.

VOVIO, C. L. Impactos da escolarização: pesquisa sobre a produção de textos em educação de jovens e adultos. In: REUNIÃO ANUAL DA ANPEd, 23., 2000 Caxambu. Anais... Caxambu: ANPEd, 2000. 1CD-ROM.

VYGOTSKY, L. S Teoria e método em psicologia. São Paulo: Martins Fontes, 1996.

. O desenvolvimento psicológico na infância São Paulo: Martins Fontes, 1998.

Psicologia da arte. São Paulo: Martins Fontes, 1999.

A tragédia de Hamlet. príncipe da Dinamarca. São Paulo: Martins Fontes, 1999.

Psicologia pedagógica. São Paulo: Martins Fontes, 2000.

. A construção do pensamento e da linguagem. São Paulo: Martins Fontes, 2001.

. Psicologia pedagógica. Porto Alegre: Artmed, 2003. Edição Comentada.

Obras escogidas II. Madrid: Visor, 1982.

. A formação social da mente. São Paulo: Martins Fontes, 1991.

. Pensamento e linguagem. São Paulo: Martins Fontes, 1987.

. Fundamentos da defectologia. Madri: Visor, 1997. Obras escogidas V.

. La imaginacion y el arte em la infância. México: Ediciones Hispânicas, 1987.

. Historia del desarrollo de las funciones psíquicas superiores. Madri: Visor, 1995. Obras escogidas III.

VYGOTSKY, L. S.; LURIA, A. R. Estudos sobre a história do comportamento. Porto Alegre: Artes Médicas, 1996.

. Psicologia e pedagogia: bases psicológicas da aprendizagem e do desenvolvimento. São Paulo: Editora Moraes, 1991.

. Linguagem, desenvolvimento e aprendizagem. São Paulo: İcone, 1988.

WERTSCH, J. V. Vygotsky y la formación social de la mente. Barcelona: Paidós,1985.

et al. (Orgs.) Estudos socio-culturais da mente. Porto Alegre: ARTMED, 1998.

ZORZAL, M. F.; BASSO, I. S. Por uma ontologia da criatividade: uma abordagem sócio-cultural. In: REUNIÃO ANUAL DA ANPEd, 24., 2001, Caxambu. Anais... Caxambu: ANPEd, 2001. 1CD-ROM.

\section{Obras analisadas ${ }^{13}$}

AMORIM, K.S.; YAZLLE, C.; FERREIRA, M. C. R. Saúde e doença em ambientes coletivos de educação da criança de 0 a 6 anos. In.: REUNIÃO ANUAL DA ANPEd, 22., 1999, Caxambu. Anais... Caxambu: ANPEd, 1999. 1CD-ROM HISTÓRICO 2002. ${ }^{14}$

ARAÚJO, J.; BAIRRAL, M. A.; RODRIGUEZ, J. G. Negociações docentes em aulas de geometria colaborativa usando computador. In: REUNIÃO ANUAL DA ANPEd, 24., 2001, Caxambu. Anais... Caxambu: ANPEd, 2001. 1CD-ROM.

BARBOSA, I. G. Formação de conceitos: discutindo uma versão sócio-histórico-dialética. In: REUNIÃO ANUAL DA ANPEd, 21., 1998, Caxambu. Anais... Caxambu: ANPEd, 1998. 1CD-ROM HISTÓRICO 2002. 
BARROCO, S. M. S. Psicologia educacional e a arte: desvendando o homem contemporâneo. In: REUNIÃO ANUAL DA ANPEd, 26., 2003, Poços de Caldas. Anais... Poços de Caldas: ANPEd, 2003. 1CD-ROM.

BRAGA, S. M. 0 fracasso escolar nas vozes de um grupo de alunos e alunas com história de repetência. In: REUNIÃO ANUAL DA ANPEd, 21., 1998, Caxambu. Anais... Caxambu: ANPEd, 1998. 1CD-ROM HISTÓRICO 2002.

BRANCO, M. T. C. Identidade e educação dos jovens sem terra. In: REUNIÃO ANUAL DA ANPEd, 25., 2002, Caxambu. Anais... Caxambu: ANPEd, 2002. 1CD-ROM.

BRANDE, C.; MONTEIRO, H. 0 olhar dos alunos sobre os processos e tempos de aprendizagem na linguagem escrita. In: REUNIÃO ANUAL DA ANPEd, 26., 2003, Poços de Caldas. Anais... Poços de Caldas: ANPEd, 2003. 1CD-ROM.

CASTANHO, M. E. L. M. Prática docente no ensino superior e história oral temática. In: REUNIÃO ANUAL DA ANPEd, 23., 2000, Caxambu. Anais... Caxambu: ANPEd, 2000. 1CD-ROM.

CÔCO, V. 0 processo de socialização com a prática e a prática docente: implicações para a formação de professores. In: REUNIÃO ANUAL DA ANPEd, 24., 2001, Caxambu. Anais... Caxambu: ANPEd, 2001. 1CD-ROM.

CONTIJO, C. M. M. A escrita e a leitura de textos na fase inicial e alfabetização. In: REUNIÃO ANUAL DA ANPEd, 26., 2003, Poços de Caldas. Anais... Poços de Caldas: ANPEd, 2003. 1CD-ROM.

COSTA, M. F. V. jogo simbólico, discurso e escola; uma leitura dialógica do lúdico. In: REUNIÃO ANUAL DAANPEd, 26., 2003, Poços de Caldas. Anais... Poços de Caldas: ANPEd, 2003. 1CD-ROM.

COSTA, S. S. G. A interpretação de textos poéticos em pares e o processo de interação. In: REUNIÃO ANUAL DA ANPEd, 25., 2002, Caxambu. Anais... Caxambu: ANPEd, 2002. 1CD-ROM.

DAMAZIO, A 0 desenvolvimento de conceitos matemáticos no processo extrativo de carvão: uma abordagem histórico-cultural. In: REUNIÃO ANUAL DA ANPEd, 23., 2000, Caxambu. Anais... Caxambu: ANPEd, 2000. 1CD-ROM.

DAMIANI, M. F. As “interações ensinantes” de professoras de sucesso: aprendizagem guiada e imitação. In: REUNIÃO ANUAL DA ANPEd, 23., 2000, Caxambu. Anais... Caxambu: ANPEd, 2000. 1CD-ROM.

DAVIS, C.; PONTES, J. F. Concepções de desenvolvimento, de aprendizagem e a prática dos fisioterapeutas. In: REUNIÃO ANUAL DA ANPEd, 22., 1999, Caxambu. Anais... Caxambu: ANPEd, 1999. 1CD-ROM HISTÓRICO 2002.

DICKEL, A. As crianças e suas experiências; o mundo invadindo a escola. In: REUNIÃO ANUAL DA ANPEd, 24., 2001, Caxambu. Anais... Caxambu: ANPEd, 2001. 1CD-ROM.

DORZIAT, A. Diferentes olhares sobre a surdez e suas implicações educacionais. In: REUNIÃO ANUAL DA ANPEd, 26., 2003, Poços de Caldas. Anais... Poços de Caldas: ANPEd, 2003. 1CD-ROM.

FACCI, M. G. D. 0 psicólogo nas escolas municipais de Maringá: a história de um trabalho e a análise de seus fundamentos teóricos. In: REUNIÃO ANUAL DA ANPEd, 22., 1999, Caxambu. Anais... Caxambu: ANPEd, 1999. 1CD-ROM HISTÓRICO.

FERREIRA, M. C. C. A escolarização da pessoa com deficiência mental. In: REUNIÃo ANUAL DA ANPEd, 22., 1999, Caxambu. Anais... Caxambu: ANPEd, 1999. 1CD-ROM HISTÓRICO 2002.

FONTANA, R. A. C. a inclusão dos professores na Educação Inclusiva. In: REUNIÃO ANUAL DA ANPEd, 24., 2001, Caxambu. Anais... Caxambu: ANPEd, 2001. 1CD-ROM.

FREITAS, M. T. A. Compreendendo práticas contemporâneas de leitura e escrita. In: REUNIÃO ANUAL DA ANPEd, 21., 1998, Caxambu. Anais... Caxambu, ANPEd, 1998. 1CD-ROM HISTÓRICO 2002.

. No discurso de adolescentes, as práticas de leitura e escrita na escola. In: REUNIÃO ANUAL DA ANPEd, 22., 1999, Caxambu. Anais... Caxambu, ANPEd, 1999. 1CD-ROM HISTÓRICO 2002. 2000.

As apropriações do pensamento de Vygotsky no Brasil: um tema em debate. Psicologia e Educação, São Paulo, p. 9-28, 
Escrita teclada: uma nova forma de escrever? In: REUNIÃO ANUAL DA ANPEd, 23., 2000, Caxambu. Anais... Caxambu, ANPEd, 2000. 1CD-ROM.

GARCIA. R. M. C. Interações voltadas à cidadania e à filantropia na escolarização de sujeitos que apresentam seqüelas motoras. In: REUNIÃO ANUAL DA ANPEd, 22., 1999, Caxambu. Anais... Caxambu: ANPEd, 1999. 1CD-ROM HISTÓRICO.

GERKEN, C. H. S. A razão e o outro em Lévy-Bruhl: notas para estudo de um diálogo com a psicologia sócio-histórica de Vygotsky. In: REUNIÃO ANUAL DA ANPEd, 23., 2000, Caxambu. Anais... Caxambu, ANPEd, 2000. 1CD-ROM.

Escolarização e apropriação da escrita nas aldeias Xacribá: elementos da teoria psicológica necessária. In: REUNIÃo ANUAL DA ANPEd, 24., 2001, Caxambu. Anais... Caxambu, ANPEd, 2001. 1CD-ROM.

Equação oralidade e escrita na psicologia: soluções contemporâneas. In: REUNIÃO ANUAL DA ANPEd, 22., 1999, Caxambú. Anais... Caxambu, ANPEd, 1999. 1CD-ROM HISTÓRICO 2002.

GESUELI, Z. M.; GÓES, M. C. R. de. A língua de sinais na elaboração da criança surda sobre a escrita. In: REUNIÃO ANUAL DA ANPEd, 21., 1998, Caxambu. Anais... Caxambu: ANPEd, 1998. 1CD-ROM HISTÓRICO 2002.

GÓES, M. C. R. 0 jogo imaginário na infância: a linguagem e a criação. In: REUNIÃO ANUAL DA ANPEd, 23., 2000 a, Caxambú. Anais... Caxambu, ANPEd, 2000. 1CD-ROM.

0 brincar de crianças surdas: examinando a linguagem no jogo imaginário. In: REUNIÃO ANUAL DA ANPEd, 24., 2001, Caxambú. Anais... Caxambu, ANPEd, 2001. 1CD-ROM.

GOULART, C.; KRAMER, S. Alfabetização, leitura, escrita: 25 anos da ANPEd e 100 anos de Drummond. Revista Brasileira de Educação, São Paulo, n. 21. p.127-146,set/out/nov/dez. 2002.

GOULART. M. I. M. A exploração do mundo natural pelas crianças: a construção do conhecimento na educação infantil. In: REUNIÃO ANUAL DA ANPEd, 25., 2002, Caxambu. Anais... Caxambu: ANPEd, 2002. 1CD-ROM.

HERNANDES, M. L. Q. G. A professora em constituição nas relações de trabalho: uma aproximação do conceito de autonomia. In: REUNIÃO ANUAL DA ANPEd, 25., 2002, Caxambu. Anais... Caxambu: ANPEd, 2002. 1CD-ROM.

JOBIM e SOUZA, S.; PEREIRA, R. M. R. Infância, conhecimento e contemporaneidade. In: REUNIÃO ANUAL DA ANPEd, 21., 1998, Caxambu. Anais... Caxambu: ANPEd, 1998. 1CD-ROM HISTÓRICO 2002.

JUNIOR, A. J. S. Educação Matemática; 0 singular e o coletivo na produção de saberes docentes. In: REUNIÃO ANUAL DA ANPEd, 24., 2001, Caxambu. Anais... Caxambu: ANPEd, 2001. 1CD-ROM.

KESSLER, M. C.; FISCHER, M. C. B. Desenvolvendo habilidades cognitivas através da matemática. In: REUNIÃO ANUAL DA ANPEd, 22., 1999, Caxambu. Anais... Caxambu: ANPEd, 1999. 1CD-ROM HISTÓRICO 2002.

KISHIMOTO, T. M. Salas de aulas nas escolas e o uso de brinquedos e materiais pedagógicos. In: REUNIÃO ANUAL DAANPEd, 23., 2000, Caxambu. Anais... Caxambu: ANPEd, 2000. 1CD-ROM.

LACERDA, C. B. F. A inserção da criança surda em classe de crianças ouvintes: focalizando a organização do trabalho pedagógico. In: REUNIĨ̃O ANUAL DA ANPEd, 23., 2000, Caxambu. Anais... Caxambu: ANPEd, 2000. 1CD-ROM.

LEAL, T. F.; LUZ, P. S. Produção de textos narrativos em pares: reflexões sobre o processo de interação. In: REUNIÃO ANUAL DA ANPEd, 23., 2000, Caxambu. Anais... Caxambu: ANPEd, 2000. 1CD-ROM.

LEMOS, T. V. Nas palavras do escritor: um ensaio sobre a constituição da subjetividade na infância. In: REUNIÃO ANUAL DA ANPEd, 25., 2002, Caxambú. Anais... Caxambu: ANPEd, 2002. 1CD-ROM.

LIBÂNEO, J. C. A didática e a aprendizagem do pensar e do aprender: Davidov e a teoria histórico-cultural da atividade. In: REUNIÃO ANUAL DA ANPEd, 26., 2003, Poços de Caldas. Anais... Poços de Caldas: ANPEd, 2003. Disponível em: <http:// www.anped.org.br>. 
MACEDO, M. S. A. N.; MORTIMER, E. F. A dinâmica discursiva na sala de aula e a apropriação da escrita. In.: REUNIÃO ANUAL DA ANPEd, 22., 1999, Caxambu. Anais... Caxambu: ANPEd, 1999. 1CD-ROM HISTÓRICO 2002.

MARANDINO, M.; GOUVÊA, G.; AMARAL, D.P. A ciência, o brincar e os espaços não-formais de educação. In: REUNIÃO ANUAL DA ANPEd, 21., 1998, Caxambu. Anais... Caxambu: ANPEd, 1998. 1CD-ROM HISTÓRICO 2002.

MARQUES, L. P. Professores de alunos com deficiência mental: formação e concepções. In: REUNIÃO ANUAL DA ANPEd, 24. 2001, Caxambu. Anais... Caxambu: ANPEd, 2001. 1CD-ROM.

MEIRA, M. E. M. 0 pensamento crítico em psicologia da educação: algumas contribuições da pedagogia histórico-crítica e da psicologia histórico-cultural. In: REUNIÃO ANUAL DA ANPEd, 23., 2000, Caxambú. Anais... Caxambu: ANPEd, 2000. 1CD-ROM.

MELLO, R. R.; et al. Concepções de professoras das series iniciais do ensino fundamental sobre o ensino da língua. In: REUNIÃO ANUAL DA ANPEd, 23., 2000, Caxambu. Anais... Caxambu: ANPEd, 2000. 1CD-ROM.

MICARELLO, H. A. L. S. Leitura e escrita no contexto escolar: encontros e desencontros. In: REUNIÃO ANUAL DA ANPEd, 21., 1998, Caxambu. Anais... Caxambu: ANPEd, 1998. 1CD-ROM HISTÓRICO 2002.

MIGUEL, J. C. A implementação curricular como uma ação cultural da escola. In: REUNIÃO ANUAL DA ANPEd, 26., 2003, Poços de Caldas. Anais... Poços de Caldas: ANPEd, 2003. 1CD-ROM.

MILLER, S. 0 trabalho epilingüístico na produção textual escrita. In: REUNIÃO ANUAL DA ANPEd, 26., 2003, Poços de Caldas. Anais... Poços de Caldas: ANPEd, 2003. 1CD-ROM.

MIRANDA, T. G. Caminhos para construção do conhecimento e da subjetividade com alunos portadores de necessidades especiais. In: REUNIÃO ANUAL DA ANPEd, 22., 1999, Caxambu. Anais... Caxambu: ANPEd, 1999. 1CD-ROM HISTÓRICO 2002.

MONTEIRO, M. S. Linguagem e diversidade no contexto da classe especial. In: REUNIÃO ANUAL DA ANPEd, 22., 1999, Caxambu. Anais... Caxambu: ANPEd, 1999. 1CD-ROM HISTÓRICO 2002.

MOURA, M. O.; ARAÚJO, E. S.; ALARCÃO, I.; TAVARES, J. Formar e formar-se na atividade de ensino de matemática. In: REUNIÃO ANUAL DA ANPEd, 24., 2001, Caxambu. Anais... Caxambu: ANPEd, 2001. 1CD-ROM.

MOURA, M. P. Desenvolvimento do pensamento: um estudo sobre formação de conceitos com jovens e adultos em processo de escolarização. In: REUNIÃO ANUAL DA ANPEd, 23., 2000, Caxambú. Anais... Caxambu: ANPEd, 2000. 1CD-ROM.

MUGRABI, E. Operações psico-lingüísticas e suas implicações didáticas: uma problemática para a educação de jovens e adultos. In: REUNIÃO ANUAL DA ANPEd, 22., 1999, Caxambu. Anais... Caxambu: ANPEd, 1999. 1CD-ROM HISTÓRICO 2002.

NORONHA, A. C.; MOURA, P. D. V. F.; SOUZA, C. A. D. Tornando-se professor. In: REUNIÃO ANUAL DA ANPEd, 23., 2000, Caxambu. Anais... Caxambu: ANPEd, 2000. 1CD-ROM.

OLIVEIRA, L. A. A escrita do surdo: relação de texto e concepção. In: REUNIÃO ANUAL DA ANPEd, 24., 2001, Caxambu. Anais... Caxambu: ANPEd, 2001. 1CD-ROM.

. A constituição da linguagem escrita do aluno surdo, na escola regular, à luz da perspectiva sócio-histórica. In: REUNIÃO ANUAL DA ANPEd, 26., 2003, Poços de Caldas. Anais... Poços de Caldas: ANPEd, 2003. 1CD-ROM.

OLIVEIRA, M. C. K. Jovens e adultos como sujeitos de conhecimento e aprendizagem. Revista Brasileira de Educação, São Paulo, n. 12, p. 59-73, set./dez. 1999.

PADILHA, A. M. L. Constituição do processo de simbolização: uma proposta pedagógica destinada aos deficientes mentais a partir da contribuição da perspectiva histórico-cultural do desenvolvimento. In: REUNIÃO ANUAL DA ANPEd, 22., 1999, Caxambu. Anais... Caxambu: ANPEd, 1999. 1CD-ROM HISTÓRICO 2002.

. A constituição do sujeito simbólico: para além dos limites impostos à deficiência mental. In: REUNIÃO ANUAL DA ANPEd, 23., 2000, Caxambú. Anais... Caxambu: ANPEd, 2000. 1CD-ROM. 
PARREIRA, P. C. Jovens e adultos em processo de escolarização: especificidades etárias e sócio-culturais. In: REUNIÃO ANUAL DA ANPEd, 24., 2001, Caxambu. Anais... Caxambu: ANPEd, 2001. 1CD-ROM.

PEREIRA, A. P. M. S. 0 processo de aprendizagem através das práticas discursivas em uma classe de aceleração da aprendizagem. In: REUNIÃO ANUAL DA ANPEd, 25., 2002, Caxambú. Anais... Caxambu: ANPEd, 2002. 1CD-ROM.

PEREIRA, R. M. R.; SALGADO, R. G.; JOBIM E SOUZA, S. Pesquisando infância e televisão: algumas considerações teóricometodológicas. In: REUNIÃO ANUAL DA ANPEd, 25., 2002, Caxambu. Anais... Caxambu: ANPEd, 2002. 1CD-ROM.

PINO, A. A psicologia concreta de Vygotsky: implicações para a educação. In: REUNIÃO ANUAL DA ANPEd, 22., 1999, Caxambu. Anais... Caxambu, ANPEd, 1999. 1CD-ROM HISTÓRICO 2002.

PRADO, P. D. Creche, brincadeira e antropologia: um trio instigante numa experiência de pesquisa em Educação Infantil. In: REUNIÃO ANUAL DA ANPEd, 21., 1998, Caxambu. Anais... Caxambu: ANPEd, 1998. 1CD-ROM HISTÓRICO 2002.

QUEIROZ, D. S. de. Interlocuções entre psicologia e educação. In: REUNIÃO ANUAL DA ANPEd, 26., 2003, Poços de Caldas. Anais... Poços de Caldas: ANPEd, 2003. 1CD-ROM.

REIS, R. M. C. Aprendendo as diferenças em classes de alfabetização. In: REUNIÃO ANUAL DA ANPEd, 26., 2003, Poços de Caldas. Anais... Poços de Caldas: ANPEd, 2003. 1CD-ROM.

ROSEMBERG, C. R. Los mecanismos de influência educativa em los primeros años de la escolaridad. Contextos de aprendizaje y "contextos cognitivos". In: REUNIÃO ANUAL DA ANPEd, 23., 2000, Caxambu. Anais... Caxambu: ANPEd, 2000. 1CD-ROM.

ROSEMBERG, D. S. 0 processo de formação continuada de professores universitários: do instituto ao instituinte. In.: REUNIÃO ANUAL DA ANPEd, 23., 2000, Caxambu. Anais... Caxambu: ANPEd, 2000. 1CD-ROM.

ROSSOLEN, R. 0 cultural e o afetivo nas vozes dos alunos sobre resolução de problemas de matemática. In: REUNIÃO ANUAL DA ANPEd, 23., 2000, Caxambu. Anais... Caxambu: ANPEd, 2000. 1CD-ROM.

ROURE, S. A. G. Concepções de indisciplina escolar e limites do psicologismo na educação. In: REUNIÃO ANUAL DA ANPEd, 24., 2001, Caxambu. Anais... Caxambu: ANPEd, 2001. 1CD-ROM.

SALGADO, R. G. Escrevendo suas histórias por "linhas tortas": de meninos de um internato. In: REUNIÃO ANUAL DA ANPEd, 23., 2000, Caxambu. Anais... Caxambu: ANPEd, 2000. 1CD-ROM.

SALVADOR, C. M. A.; NACARATO, A. M. Sentidos atribuídos ao zero por alunos da 6 a série. In: REUNIÃO ANUAL DA ANPEd, 26., 2003, Poços de Caldas. Anais... Poços de Caldas: ANPEd, 2003. 1CD-ROM.

SCHLINDWEIN, L. M. Uma investigação das transformações conceituais de professores em situação de formação continuada. In: REUNIÃO ANUAL DA ANPEd, 25., 2002, Caxambu. Anais... Caxambu: ANPEd, 2002. 1CD-ROM.

SFORNI, M. S. F. Aprendizagem conceitual e organização do ensino: contribuições da teoria da atividade. In: REUNIÃO ANUAL DA ANPEd, 26., 2003, Poços de Caldas. Anais... Poços de Caldas: ANPEd, 2003. 1CD-ROM.

SHIMA, S. M. B. Psicologia educacional e a arte: desvendando o homem contemporâneo. In: REUNIÃO ANUAL DA ANPEd, 26., 2003, Poços de Caldas. Anais... Poços de Caldas: ANPEd, 2003. 1CD-ROM.

SILVA, F. C. T. Desenvolvimento e aprendizagem: deficiência mental sob a ótica das teorias cognitivas. In: REUNIÃO ANUAL DA ANPEd, 21., 1998, Caxambu. Anais... Caxambu: ANPEd, 1998. 1CD-ROM HISTÓRICO 2002.

SILVA, M. A. 0. 0 discurso dos professores sobre a formação continuada. In: REUNIÃO ANUAL DA ANPEd, 24., 2001, Caxambu. Anais... Caxambu: ANPEd, 2001. 1CD-ROM.

SILVA, S. N. S. A centralidade das tarefas escolares nas práticas escolares construtivistas. In: REUNIÃO ANUAL DA ANPEd, 23., 2000, Caxambu. Anais... Caxambu: ANPEd, 2000. 1CD-ROM. 
SOUSA, C. A. D. Tornando-se professor. In: REUNIÃO ANUAL DA ANPEd, 23., 2000, Caxambu. Anais... Caxambu: ANPEd, 2000. 1CD-ROM.

SOUZA, T. B.; OSÓRIO, A. M. N. A mediação pedagógica na produção de texto: um diálogo possível e necessário. In: REUNIÃO ANUAL DA ANPEd, 26., 2003, Poços de Caldas. Anais... Poços de Caldas: ANPEd, 2003. 1CD-ROM.

TASSONI, E. C. M. Afetividade e aprendizagem: a relação professor-aluno. In: REUNIÃO ANUAL DA ANPEd, 23., 2000, Caxambu. Anais... Caxambu: ANPEd, 2000. 1CD-ROM.

TERRA, D. M. C. "Ler desenho" e outras reflexões sobre alfabetização e construção do conhecimento: a palavra do trabalhador. In: REUNIÃO ANUAL DA ANPEd, 24., 2001, Caxambu. Anais... Caxambu: ANPEd, 2001. 1CD-ROM.

TOLEDO, M. E. R. O. As estratégias metacognitivas de pensamento e o registro matemático de adultos pouco escolarizados. In: REUNIÃO ANUAL DA ANPEd, 24., 2001, Caxambu. Anais... Caxambu: ANPEd, 2001. 1CD-ROM.

TULESKI, S. C. Para ler Vygotski: recuperando a historicidade perdida. In: REUNIÃO ANUAL DA ANPEd, 23., 2000, Caxambu. Anais... Caxambu: ANPEd, 2000. 1CD-ROM.

VOVIO, C. L. Impactos da escolarização: pesquisa sobre a produção de textos em educação de jovens e adultos. In: REUNIÃO ANUAL DA ANPEd, 23., 2000 Caxambu. Anais... Caxambu: ANPEd, 2000. 1CD-ROM.

ZORZAL, M. F.; BASSO, I. S. Por uma ontologia da criatividade: uma abordagem sócio-cultural. In: REUNIÃO ANUAL DA ANPEd, 24., 2001, Caxambu. Anais... Caxambu: ANPEd, 2001. 1CD-ROM.

Recebido em 16.02.04

Aprovado em 15.04.04

Maria Teresa de Assunção Freitas é professora da Faculdade de Educação da UFJF, doutora em Educação (PUC-Rio), pesquisadora do CNPq, autora de vários livros, entre eles: 0 pensamento de Vygotsky e Bakhtin no Brasil (Papirus,1994); Vygotsky e Bakhtin - Psicologia e educação: um intertexto (Ática, 1994); Vygotsky: um século depois (Edufjf, 1998).

13. Constam desta relação 89 textos, embora tenham sido analisados 87 trabalhos. Explica-se isso, pois, textos apresentados numa sessão conjunta de trabalhos encomendados foram computados como apenas um trabalho.

14. Só foi possível 0 acesso a alguns trabalhos através da publicação do CD-Rom Histórico em 2002, que reuniu grande parte dos textos apresentados em Reuniões da ANPEd anteriores à $23^{\mathrm{a}}$ Reunião. Assim, ao referenciá-los mantive as datas dos respectivos Anais indicando-0s como presentes no CDRom Histórico 2002. 